\title{
Pigeon Lake Fall Walleye, Sander vitreus, Index Netting Survey, 2004
}

Owen Watkins

Fisheries Technician

Alberta Sustainable Resource Development

Fish and Wildlife Division

Red Deer, Alberta

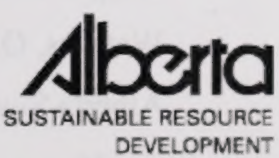

March, 2005

Fisheries Management Division Technical Report

Fish \& Wildlife 
Pigeon Lake Fall Walleye, Sander vitreus, Index Netting Survey, 2004; Data Report

\section{PERMISSION TO QUOTE}

This report contains preliminary data and interpretations that may be subject to future revision. Persons who wish to quote from this report, cite it in a bibliography, or use it in any other form must first obtain permission from: Director of Fisheries Management, Alberta Fish and Wildlife Division; Regional Head of Fisheries, Southeast Region; or the author.

Keywords:

Pigeon Lake 2004, FWIN, Fall Walleye Index Netting

Author contact information:

Owen Watkins

Alberta Sustainable Resource Development

Fish and Wildlife Division

250 Diamond Ave.

Spruce Grove, Alberta

$\mathrm{T} 7 \mathrm{X}-4 \mathrm{C} 7$

Owen.Watkins@gov.ab.ca

Suggested citation:

Watkins, O.B. 2005. Pigeon Lake Fall Walleye (Sander vitreus) Index Netting Survey. Alberta Sustainable Resource Development, Fish and Wildlife Division. Data Report, pp. 46 
Pigeon Lake Fall Walleye, Sander vitreus, Index Netting Survey, 2004; Data Report

\section{ABSTRACT}

An assessment of the Pigeon Lake walleye population was completed September 22, 2004 using the Fall Walleye Index Netting (FWIN) protocol. Our objectives were to determine walleye stock status, walleye recruitment and to evaluate individual walleye condition and whether hooking injuries were responsible for any poor conditions observed. Six nets were set resulting in a total catch of 236 walleye with a mean catch rate of 39.3 walleyes/net. Due to high population density and poor recruitment, we assessed the walleye population to be of vulnerable status. Only 2 stocked year-classes, 1999 and 1998 were supporting a majority of the population. With low recruitment and close proximity to large city centers, the data clearly suggests that the walleye population needs to be carefully managed. 
Pigeon Lake Fall Walleye, Sander vitreus, Index Netting Survey, 2004; Data Report

\section{ACKNOWLEDGEMENTS}

Fisheries Management from the Southeast Region administrative unit (SE3) would like to acknowledge the efforts of staff and other individuals involved in the Fall Walleye Index Netting program at Pigeon Lake in 2004:

- Vance Buchwald, Mike Sullivan and Kevin Wingert of Alberta Sustainable Resource Development who helped with the index netting.

- George Belter of the Millet Fish and Game Association who helped with the index netting.

- Stephen Spencer who provided ageing supplies.

- Amanda Warman who cut and mounted walleye fin-rays.

I would also like to thank Stephen Spencer and Vance Buchwald for their critical review of this report. 
Pigeon Lake Fall Walleye, Sander vitreus, Index Netting Survey, 2004; Data Report

TABLE OF CONTENTS

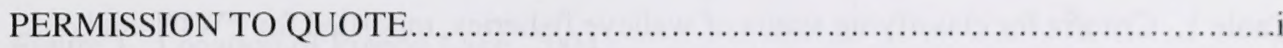

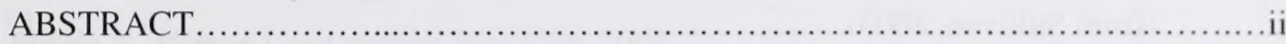

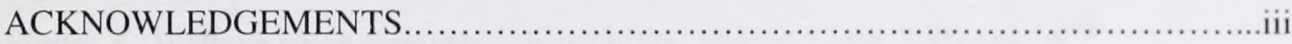

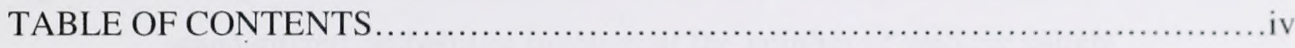

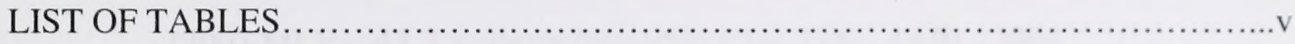

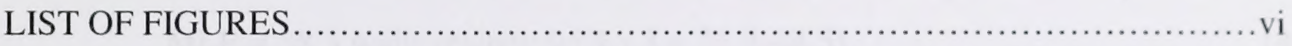

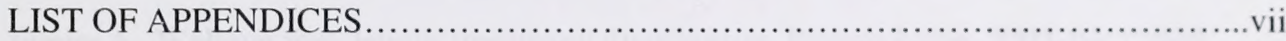

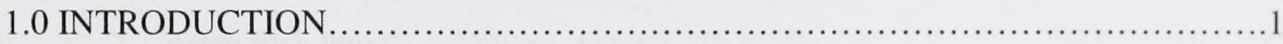

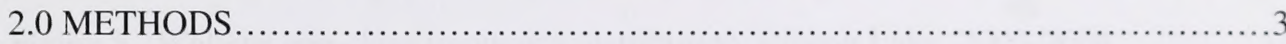

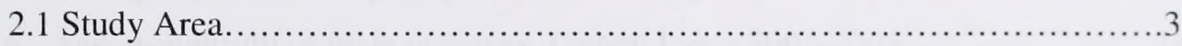

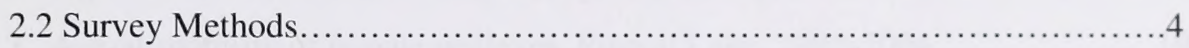

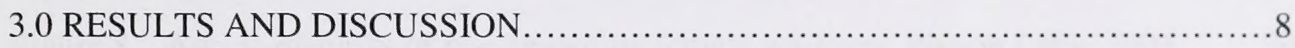

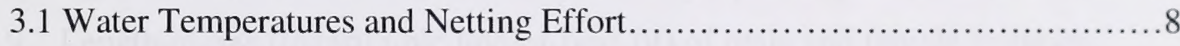

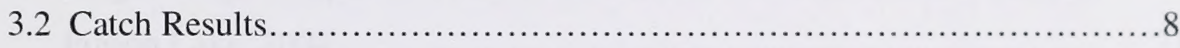

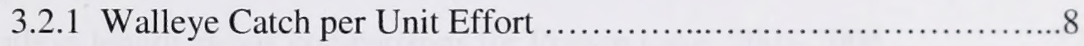

3.2.2 Fork Length Frequency Distribution 2003-2004_................9

3.2.3 Age-Class Frequency Distribution 2003-2004_................. 9

3.2.4 Age-Class Stability ........................................ 10

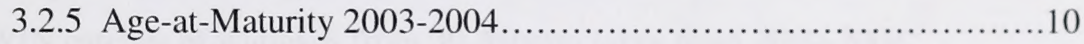

3.2.6 Length-at-Age............................................ 10

3.2.7 Catch Rate Comparison.................................... 10

3.2.8 Walleye Condition Factor and Hooking Injuries..................11

3.2.9 Von Bertalanffy Growth Curves, 2003-2004_.....................12

3.3 Walleye Ageing Considerations ......................................13

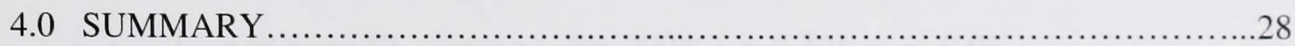

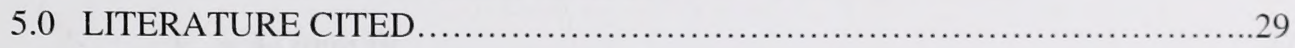

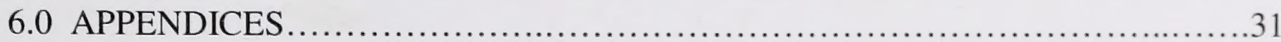


Pigeon Lake Fall Walleye, Sander vitreus, Index Netting Survey, 2004; Data Report

\section{LIST OF TABLES}

Table 1. Criteria for classifying status of walleye fisheries, modified for FWIN analysis (from Sullivan, 2003).............................................. 17 


\section{LIST OF FIGURES}

Figure 1. Location of Pigeon Lake, 2004 ............................................................. 6

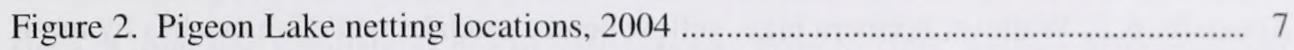

Figure 3. Walleye catch frequency distribution, Pigeon Lake, 2003-04. A standardized probability function of the number of walleye caught (2003 MLE $=43.3$ walleyes/net; 95\% CI $=37.6-48.9),(2004$ MLE $=38.3$ walleyes $/$ net $; 95 \%$ CI $=31.9-44.5$ ) 14

Figure 4. Walleye fork length frequency distribution, Pigeon Lake, 2003-04; (2004 mean fork length $=449 \mathrm{~mm}$, mean CUE $=29$ )

Figure 5. Walleye age-class frequency distribution, Pigeon Lake, 2003-2004 ............. 16

Figure 6. Age-at-maturity of male walleyes, Pigeon Lake, 2003-2004 ………........... 18

Figure 7. Age-at-maturity of female walleyes, Pigeon Lake, 2003-2004 _..................... 19

Figure 8. Age-at-maturity of non-spawning female walleyes, Pigeon Lake, 2004 ....... 20

Figure 9. Length-at-age (logarithmic line-of-best-fit) of male and female walleyes,

Pigeon Lake, 2004 21

Figure 10. Walleye length-at-age comparisons for Pigeon Lake, 2003-2004 22

Figure 11. Length-at-weight visual assessment including physical and injury conditions, Pigeon Lake, 2004 23

Figure 12. Walleye length-at-weight, Pigeon Lake, 2003-2004 24

Figure 13. FWIN catches of walleyes from 30 Alberta lakes from 2000-2004.

Error bars depict $95 \%$ confidence intervals, CUE's range from $1.3-43.9$.. 25

Figure 14. Stocked young-of-the-year walleye, Pigeon Lake, 1994-1999 26

Figure 15. Von Bertalanffy growth curves and parameters fitted to observed fork length-at-age data for Pigeon Lake, 2003; $\mathrm{k}=0.148, \mathrm{t}_{0}=-1.387$,

$\mathrm{L}_{\infty}=795 \mathrm{~mm}$ FL, Pigeon Lake, 2004; $\mathrm{k}=0.092, \mathrm{t}_{0}=-2.487$,

$\mathrm{L}_{\infty}=968 \mathrm{~mm}$ FL, Smoke Lake, 2004; $\mathrm{k}=0.301, \mathrm{t}_{0}=-0.96$,

$\mathrm{L}_{\infty}=447 \mathrm{~mm}$ FL 
Pigeon Lake Fall Walleye, Sander vitreus, Index Netting Survey, 2004; Data Report

\section{LIST OF APPENDICES}

Appendix 6.1. Catch composition from FWIN nets, Pigeon Lake, 2004

Appendix 6.2. Walleye, northern pike, yellow perch, and lake whitefish catches by mesh size, Pigeon Lake, 2004

Appendix 6.3. Statistics of the catch distribution for game fish catches, Pigeon Lake, 2004. This data is for presentation of the statistical nature of the catch distribution and are based on the geometric means values (unweighted) 34

Appendix 6.4. Walleye condition factor and hooking injury, Pigeon Lake, 2004 .... 35

Appendix 6.5. Walleye stocking shipments, Pigeon Lake, 1994-1999 .................... 36

Appendix 6.6. Walleye catches by mesh size, Pigeon Lake 2003 ............................. 37 
Pigeon Lake Fall Walleye, Sander vitreus, Index Netting Survey, 2004; Data Report

\subsection{INTRODUCTION}

In Alberta, walleyes (Sander vitreus) (formerly Stizostedion vitreum) have been subjected to high angling pressure for many years. Numerous walleye lakes in Alberta have shown signs of truncated populations due to over-harvest. Prior to 1995, walleye were managed on a province-wide scale. This management practice failed to protect individual lakes with high angling pressure. Subsequently, Alberta's Walleye Management and Recovery Plan developed by Alberta Sustainable Resource Development (Berry, 1995) was implemented to aid in the recovery of Alberta's walleye populations. This action plan was designed to manage each individual walleye population, and to classify and evaluate each individual state of exploitation.

Currently, Pigeon Lake's walleye have been classified as a collapsed population. Sport angling has been reduced to a catch and release fishery with a zero-limit walleye possession. The commercial fishery on lake whitefish was suspended in 2001 and 2002 after the walleye tolerance quota was exceeded by $272 \%$ in 2000 . The commercial fishery was also cancelled for the 2003 and 2004 seasons due to concerns that the walleye quota would again be exceeded.

Pigeon Lake is experiencing high angling pressure due to its close proximity to two city centers, the population of each center exceeding one million people. It was estimated in 2003 that anglers fished Pigeon Lake for 3.3 hours/hectare, an increase from 1.2 hours/hectare in 1999 (Patterson, 2004).

Prior to 1963-1964, Pigeon Lake's walleye were found in commercial catches, but subsequently the population died out (Mitchell and Prepas, 1990). The lake was then restocked with walleye in $1979,1980,1982$ to 1984 , resulting in a small population being reestablished. Pigeon Lake was restocked again from 1994 to 1999 (Figure 14) (Appendix 5). Walleye now appear to have been reestablished in Pigeon Lake. 
Pigeon Lake Fall Walleye, Sander vitreus, Index Netting Survey, 2004; Data Report

The purpose of the 2004 FWIN survey was to follow-up the FWIN survey from the 2003year. The main objectives of the 2004 survey were to determine walleye stock status, walleye recruitment, the extent of walleye hooking injuries and to address concerns regarding a perceived decline in walleye condition (skinny walleye). 
Pigeon Lake Fall Walleye, Sander vitreus, Index Netting Survey, 2004; Data Report

\subsection{METHODS}

\subsection{Study Area}

Pigeon Lake is located approximately $60 \mathrm{~km}$ southwest of Edmonton. Alberta (Township 46 and 47 , Range 1 West of the $5^{\text {th }}$ Meridian) in the dry mixed wood sub region of boreal mixedwood (Figure 1). This mildly eutrophic lake has a surface area of 9670 hectares (ha), a mean depth of 6.2 meters $(\mathrm{m})$, a maximum depth of $9.1 \mathrm{~m}$ with $46000 \mathrm{~m}$ of shoreline (Mitchell and Prepas, 1990).

Pigeon Lake is located in the Battle River drainage zone receiving water from several intermittent streams that drain the western and northwestern portions of the drainage basin. The outlet is Pigeon Lake Creek, which flows from the south end of the lake in a southeasterly direction to the Battle River (Mitchell and Prepas, 1990).

Pigeon Lake supports 10 fish species including walleye (Sander vitreus), northern pike (Esox lucius), yellow perch (Perca flavescens), burbot (Lota lota), lake whitefish (Coregonus clupeaformis), white sucker (Catostomus commersoni), spottail shiner (Notropis hudsonius), emerald shiner (Notropis atherinoides), trout-perch (Percopsis omiscomaycus) and Iowa darter (Etheostoma exile) (Mitchell and Prepas, 1990). 
Pigeon Lake Fall Walleye, Sander vitreus, Index Netting Survey, 2004; Data Report

\subsection{Survey Methods}

Pigeon Lake was surveyed according to the 2000 FWIN protocol developed by the Ontario Ministry of Natural Resources (Morgan, 2000). The standard FWIN net measures $109.8 \mathrm{~m}^{2}(61.0 \mathrm{~m}$ long by $1.8 \mathrm{~m}$ deep) consisting of eight ascending panels of mesh sizes: $25 \mathrm{~mm}, 38 \mathrm{~mm}, 51 \mathrm{~mm}, 64 \mathrm{~mm}, 76 \mathrm{~mm}, 102 \mathrm{~mm}, 127 \mathrm{~mm}$, and $152 \mathrm{~mm}$ with no spacers.

To distribute nets spatially, the lake was divided into $1000 \mathrm{~m}^{2}$ non-overlapping quadrants using a 1:50 000 Universal Transverse Mercator Grid (Alberta Government Geographical Information System database 2004, Figure 2). Each quadrant was numbered sequentially and divided into four $0.25 \mathrm{~km}^{2}$ sub-quadrants. Sub-quadrants were labeled clockwise, A, B, C, and D. With the use of a bathymetric map of Pigeon Lake, a second stratum, depth, divided netting effort between shallow strata (2-5m) and deep strata (5-15m). Sampling effort was allocated in proportion to the area within each stratum (shallow and deep). Sites were randomly selected using the "RANDBETWEEN" function in Microsoft Excel without replacement.

Each of these predetermined sampling sites was loaded into a GPS unit, using the center of each sub-quadrant as the target site. If the required depth was not found within $250 \mathrm{~m}$ of the target site, a new location was chosen. If the sampling site fell within $500 \mathrm{~m}$ of a nearby sampled site, a new location was chosen.

A total of six FWIN nets were set, two within the shallow stratum and four within the deep stratum. Each FWIN net was set perpendicular to shore for approximately $24 \mathrm{hrs}$ avoiding steep lake-bottom gradient drop-offs and heavy vegetated aquatic areas.

The catch from each panel were bagged separately. On a corresponding tag, the grid number and mesh size were recorded and enclosed within each bag. Walleye, northern 
pike, lake whitefish, and yellow perch were sampled. To assess condition, walleyes and northern pike were subjectively inspected for condition and hooking injury. Each walleye and northern pike in this study was assigned a number based on the following two parameters:

i) Condition factor: 1 = unusually fat, 2 = normal, 3 = unusually skinny.

ii) Hooking injury: $0=$ no injuries, $1=$ mouth/mandible injury, 2 = eye injury, 3 = internal injury (i.e., gills hanging loose, hooks in body, etc.).

Using these criteria, a walleye that was unusually skinny that had a hook in its stomach was coded 3.3 .

Ageing structures were collected from each species (walleye - left pelvic fin and operculum, northern pike - left pelvic fin and cleithrum, lake whitefish - scales, yellow perch - anal fin-rays). Each fish was measured for fork length ( $\mathrm{mm})$, total length ( $\mathrm{mm})$. and weight $(\mathrm{g})$.

Sex and maturity were determined by an internal examination. Fish were determined as mature if their gonads were deemed developed enough to spawn in the next spawning season. Female walleyes that were determined as non-spawning females (NSF) displayed mature gonadal development (had probably spawned previously), but lacked developing eggs and would not spawn during the next spawning season.

Walleye ages were determined by a slightly modified method to that described by Mackay et-al. (1990) (236 walleye). Mackay suggested that the first annulus tightly surrounding the focus indicates year one. The following formula was used to help identify the first annulus:

where:

$$
1^{\text {st }} \text { annulus }=\quad \underline{\text { rL }(\text { age }-0 ~ L)}
$$

$\mathrm{rL}=$ radius length (distance from the center of the focus to the furthest edge)

Age-0 L = hypothesized length of age- 0 walleye at time sampled

$\mathrm{L}=$ length of the sampled walleye 
Pigeon Lake Fall Walleye, Sander vitreus, Index Netting Survey, 2004; Data Report

All data were analyzed and written using Microsoft Office XP Professional. A complete data set from this study is stored in the Alberta Sustainable Resource Development (ASRD) Fisheries Management Information System database (FMIS). 
Pigeon Lake Fall Walleye, Sander vitreus, Index Netting Survey, 2004: Data Report

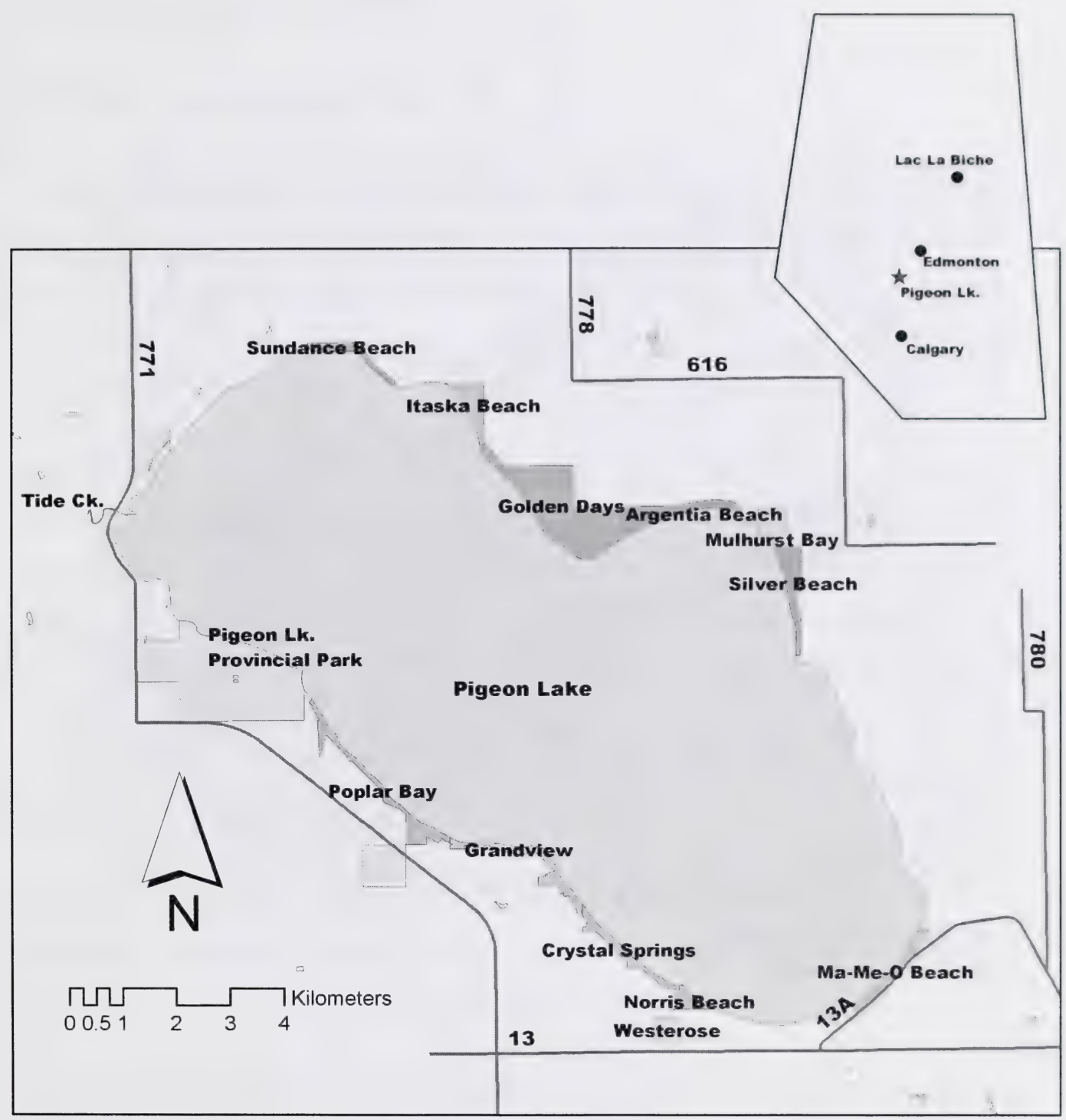

Figure 1. Location of Pigeon Lake, 2004. 
Pigeon Lake Fall Walleye, Sander vitreus, Index Netting Survey, 2004; Data Report

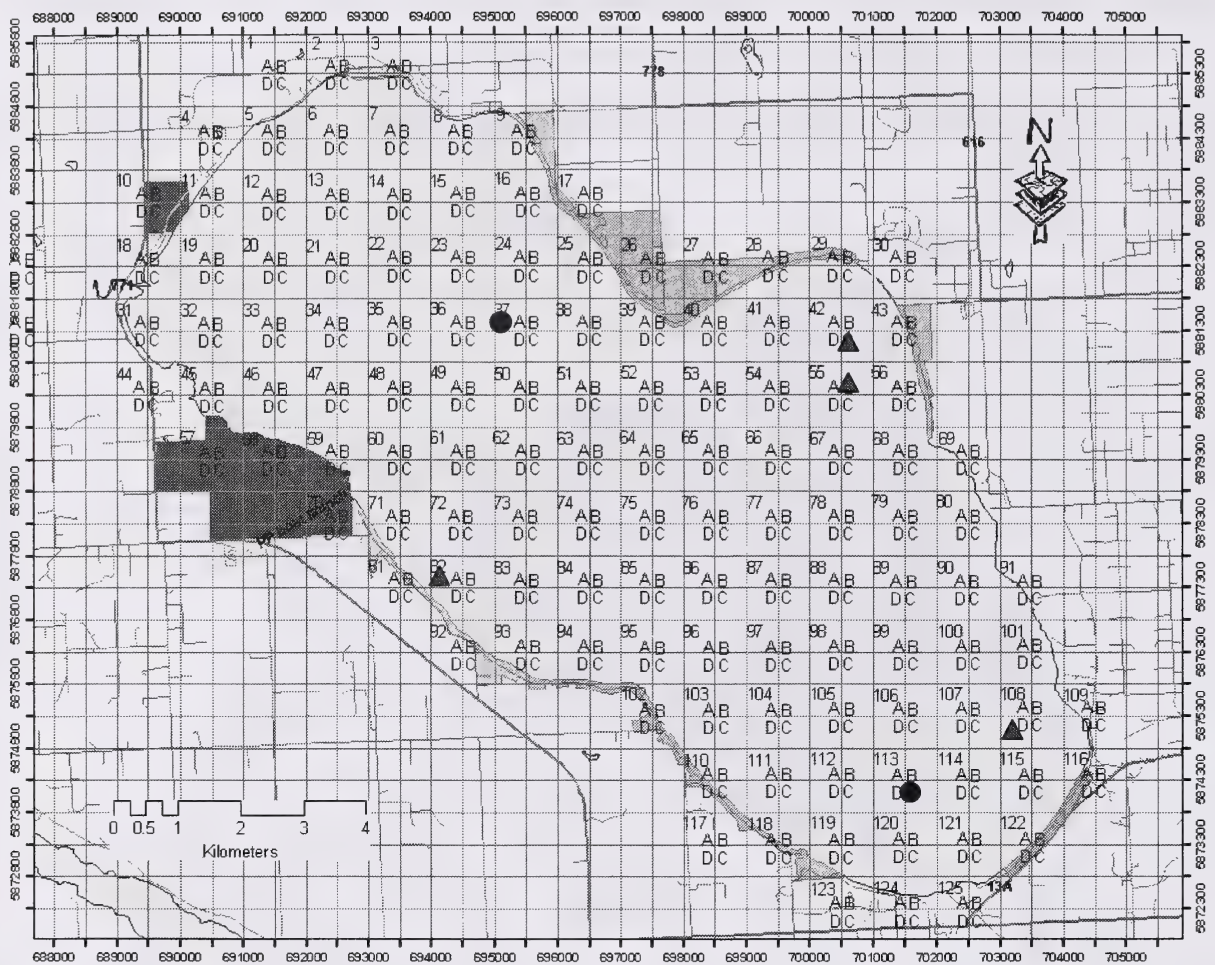
$\triangle$ Shallow Set $(2-5 m)$
- Deep Set $(>5 \mathrm{~m})$

Figure 2. Pigeon Lake Net Locations, 2004. 
Pigeon Lake Fall Walleye, Sander vitreus, Index Netting Survey. 2004: Data Repor!

\subsection{RESULTS AND DISCUSSION}

\subsection{Water Temperatures and Netting Effort}

The FWIN surveys began on September 20, 2004 and concluded on September 22, $20(04$ during which water temperatures were at a constant $10^{\circ} \mathrm{C}$ (Appendix 1). The mean soak time was 22.5 hours per net with a range of 21.5 to 23.6 hours.

\subsection{Catch Results}

The FWIN catch during 2004 totaled 325 fish representing 7 species with a mean catch of $54.2 \mathrm{fish} / \mathrm{net}$ (Appendix 1). The two deep sets caught 93 fish (46.5 fish/net); the four shallow sets caught 232 fish (58.0 fish/net). Walleye were the most frequently caught species $(n=236,72.6 \%)$, followed by lake whitefish $(n=69,21.2 \%)$, northern pike $(n=$ $12,3.7 \%)$, yellow perch $(n=3,0.9 \%)$, spottail shiner $(n=3,0.9 \%)$, and troutperch $(n=$ $2,0.6 \%)$.

\subsubsection{Walleye Catch per Unit Effort}

Catch per unit effort (CUE) is a measure (number or weight) of species relative abundance, captured over a period of time. CUE metrics were calculated from random samples that provide an unbiased measure of relative abundance.

During the 2004 FWIN, walleyes were caught in all mesh sizes, with the highest catch in the $64 \mathrm{~mm}$ panel at 9.33 walleyes/net (Appendix 2). Shallow sets caught an average of 44.3 walleyes/net (range 35-49 walleye); the deep sets caught an average of 29.5 walleyes/net (range 29-30). The weighted CUE was 38.3 walleyes/net and the walleye catches appeared to be normally distributed (range 29-49 walleye) (Figure 3).

In 2003, walleyes were caught in all mesh sizes, with the highest catch in the $76 \mathrm{~mm}$ section at 11.25 walleyes/net (Appendix 6). Shallow sets caught an average of 43.5 
Pigeon Lake Fall Walleye, Sander vitreus, Index Netting Survey, 2004; Data Report

walleyes/net (range 42-45) and the deep sets caught an average of 55 walleyes/net (range 53-57. The weighted CUE was 43.3 walleyes/net.

\subsubsection{F $\quad$ Length Frequency Distribution 2003-2004}

The 2004 fork length distribution ranged from 174 - 684mm (Figure 4) dominated by walleye of $430-490 \mathrm{~mm}$. Similarly, the 2003 fork length distribution ranged from 140 $698 \mathrm{~mm}$ (Figure 4) dominated by walleye of $430-500 \mathrm{~mm}$ range.

\subsubsection{Age-Class Frequency Distribution 2003 - 2004}

In 2004, the year-classes caught ranged from 0 to 12 years (Figure 5). The 1998 and 1999 year-classes ( 6 and 5 year-olds) dominated the sample. The catch rates of 1998 and 1999 year-classes were 16.3 walleyes/net and 10.2 walleyes/net, which made up $67.4 \%$ of the total catch. The 2000 year-class was the next most dominant age-class, with a catch rate of 3.67 walleyes/net. This population is predominantly supported by two ageclasses and has a mean age of 5.9 years, indicating a vulnerable fishery (Table 1).

The 2003 catch was made up of the 0 to 18 year age-classes with the 2 and 11-17 yearold age-classes missing (Figure 5). The 1997 and 1998 year-classes (6 and 5 year-olds) dominated the sample. The catch rates of the 1997 and 1998 year-classes were 9.5 walleyes/net and 27.5 walleyes/net, which made up $75.1 \%$ of the total catch. The 1996year was the next dominant age-class, which had a catch rate of 3.25 walleyes/net.

Overall in 2004, there was an increase in catch in the first 5 age-classes (ages 0-4). In 2003 , the young-of-the-year age-class was virtually missing with only 1 walleye caught ( 0.25 walleyes/net), whereas in 2004 there were 6 young-of-the-year walleyes caught (1.0 walleyes/net). In 2004, there was a slight increase in catch of the year-one age-class to 4 walleyes from 1 walleye in 2003. The two-year-old age-class showed an increase in 2004, from 0 walleyes to 10 walleyes ( 1.7 walleyes/net). In 2003, the 1998 year-class 
Pigeon Lake Fall Walleye, Sander vitreus, Index Netting Survey, 2004: Data Report

was by far the most dominant (27.5 walleyes/net) but showed a slight decrease in 2004 (16.3 walleyes/net).

\subsubsection{Age-Class Stability}

In 2004, the age structure of Pigeon Lake walleye showed a diminished representation of the 7 to 9 year-classes, and an improved representation of the 0 to 4 year-classes from 2003 (Figure 5). In 2004, walleye were generally missing from age 8 and up, but there was a slight improvement in walleye recruitment from the previous year.

\subsubsection{Age-at-Maturity $2003-2004$}

In 2004, the overall sex ratio in the FWIN catches was 1.54 females: males. $80 \%$ percent of the male population was sexually mature by age 5 and completely mature by age 6 (Figure 6). In 2004, 98\% of female walleye were sexually mature by age 7 and completely mature by age 8 (Figure 7 ). Walleye populations with sexually mature females at ages $6-7$ and sexually mature males by ages $5-7$ are an indicator of a vulnerable fishery in Alberta (Citation, Table 1).

\subsubsection{Length-at-Age}

In 2004, the growth of male walleye was more rapid than female walleye to age 3 . Beyond age 4 the female walleye began to outpace the males (Figure 10). By age 7. nearly all male and female walleye reached $50 \mathrm{~cm}$ total length.

\subsubsection{Catch Rate Comparison}

The weighted FWIN catch rate for Pigeon Lake in 2004 (38.3 walleyes/net) was 12\% lower than the 2003 catch rate at 43.3 walleyes/net (Figure 3). FWIN catches from 30 Alberta lakes ranged from 1.3 walleyes/net (Lac La Biche, 2003) to 43.9 walleyes/net 
Pigeon Lake Fall Walleye, Sander vitreus, Index Netting Survey, 2004; Data Report

(Buck Lake, 2004). Pigeon Lake CUEs from 2003-2004 are at the extreme high end of this range, only second to its close neighbor, Buck Lake (Figure 13).

\subsubsection{Walleye Condition Factor and Hooking Injuries, Pigeon Lake, 2004}

There have been reports from local anglers that many walleyes have been repetitively caught. Anglers have noted external injuries due to hooking damage, such as damaged eyes, gills and mouths. Anglers' perceptions are that the physical conditions of these walleyes are declining, perhaps due to repetitive hooking.

Walleyes were visually inspected, internally (mouth, gills, and alimentary canal) and externally (eyes, mouth and body) for hooking injuries. Four walleyes showed signs of hooking injuries (Appendix 4). Two mature female walleyes and one mature male had external hooking damage. One mature female was missing the left corner of her maxilla (healed), and was slightly below average weight (Figure 11). The second mature female had hooking damage to the upper right maxilla (healing), and although classified as a NSF (non-spawning female), was slightly above average weight. The third fish, a mature male walleye had hooking damage to its left mandible and was below overall average weight for its length. The forth walleye was a mature female with a gold jig head in its stomach. This female was considerably below overall average weight for its length.

Walleyes were visually inspected for their overall size (fat-normal-skinny) (Appendix 4). Eight walleyes were classified and recorded as 'unusually fat'. None of these walleyes had any external or internal physical injuries. Seven of these walleyes were above overall average weight based on a 'normal weight' logarithmic line (line-of-best-fit). Two mature male walleyes were classified and recorded as 'unusually skinny'; these two walleyes had no associated physical trauma.

The regression of fork length vs. weight shows that walleyes in 2004 weighed less for the same fork length than fish in 2003. The difference in weight was not noticeable in fish less than $350 \mathrm{~mm}$, but became increasingly greater in the larger fish. 


\subsubsection{Von Bertalanffy growth curves, Pigeon Lake, 200(3-20)(1)}

Growth in length is typically fastest early in life, and then decreases over time as fish reach maximum length and age. A comparison of the von Bertalanffy growth curves revealed a variance in the growth parameters $\left(\mathrm{L}_{\infty}, \mathrm{K}\right.$ and $\left.\mathrm{t}_{0}\right)$ between Pigeon Lake 2003 and 2004 (Figure 15). Pigeon Lake 2004 appears to have a slower growth rate (K) and a greater asymptotic length $\left(\mathrm{L}_{\infty}\right)$ than the 2003-year. The 5-7 year-classes show very little growth differences between the 2003-2004 years.

The following von Bertalanffy growth equation was used: $\mathrm{Lt}=\mathrm{L}_{\infty}\left(1-\mathrm{e}^{-\mathrm{k}(1-1(1))}\right)$. where:

$\mathrm{L}_{\infty}=$ maximum theoretical length (fork length infinity) that can be obtained;

$\mathrm{k}=$ growth coefficient;

$\mathrm{t}=$ time of age in years;

$\mathrm{t}_{0}=$ is the time in years when length would theoretically be equal to zero and;

$\mathrm{e}=$ exponent for natural logarithms.

$\mathrm{L}_{\infty}, \mathrm{t} 0$, and $\mathrm{k}$ were calculated using the Fishery Analysis and Simulation Tools ver. 2.1

(Slipke and Maceina, 2001). The length-at-age data were fitted to the growth model by applying the equation independently to each sample. 
Pigeon Lake Fall Walleye, Sander vitreus, Index Netting Survey, 2004; Data Report

\subsection{Walleye Ageing Considerations}

Approximately 18.5 million walleyes have been stocked in Pigeon Lake over a period of 6 years from 1994-1999 (Figure 14). There were two sizes of stocked walleyes, fry and fingerlings and of different stock genetics (Appendix 5). These walleyes were planted into Pigeon Lake at different times of the spring and summer. Pond-reared walleyes develop a stress-induced mark in the otolith microzonation during pond removal and transport. As this mark occurs on a known day, it can be used to discriminate between stocked and native individuals (Casselman, 1995).

Calcified structures may not always form a complete growth sequence through the life of the fish; false checks can be laid down; or annuli can overlie each other - especially in older fish at the margin - making interpretation difficult (Campana, 2001). In such cases, it is recommended that several readings should be made to increase the precision of the estimate. Interpreters should be made aware of the different factors influencing the formation of annular rings, i.e., native and stocked walleyes (genetic variation), including the time of year the walleyes were planted and at what stage of growth. Otherwise, these factors may tend to distort the interpreted ages. To promote ageing consistency between sampling events, it is important that a single individual interpret and apply the ages. 
Pigeon Lake Fall Walleye, Sander vitreus, Index Netting Survey, 2004: Datta Report

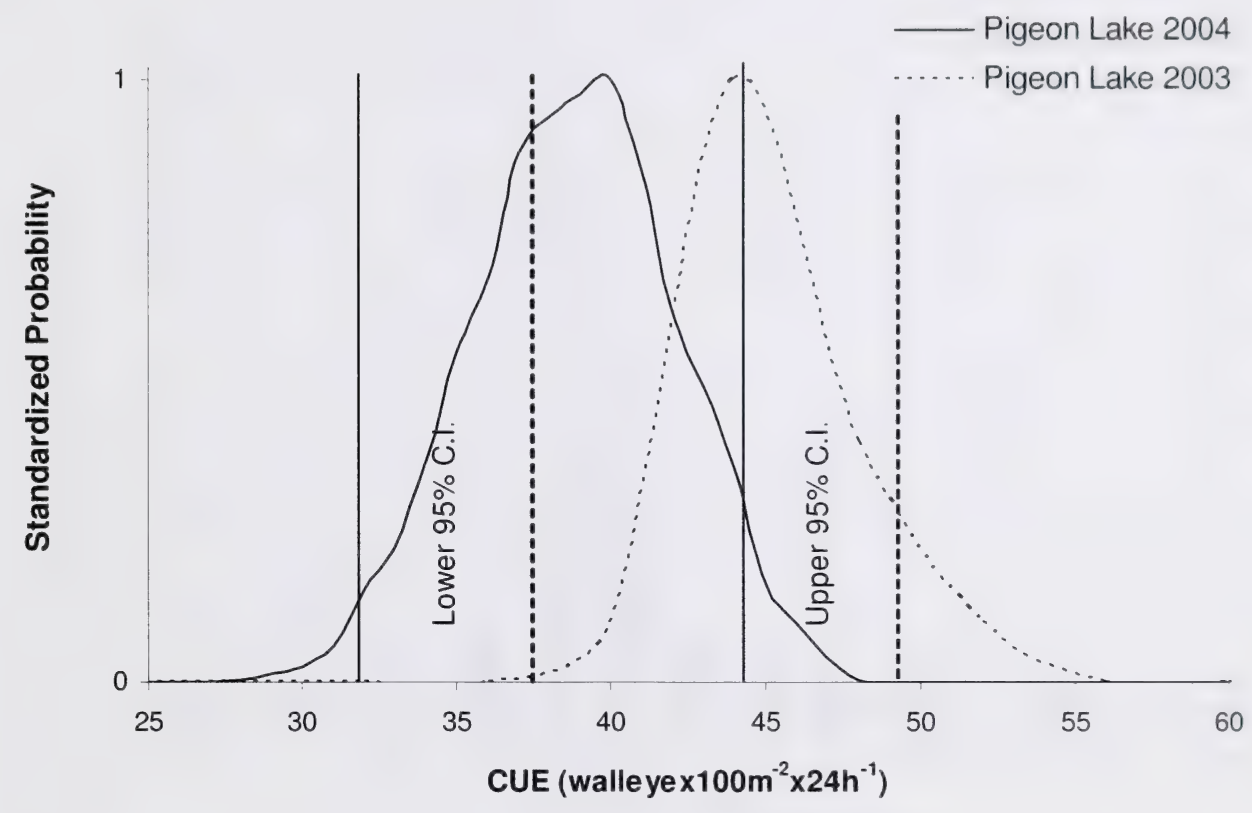

Figure 3. Walleye catch frequency distribution, Pigeon Lake, 2003-04. A standardized probability function of the number of walleyes caught ( $2003 \mathrm{MLE}=43.3$ walleyes/net: $95 \% \mathrm{CI}=37.6-48.9),(2004 \mathrm{MLE}=38.3$ walleyes $/$ net; $95 \% \mathrm{CI}=31.9-44.5)$. 
Pigeon Lake Fall Walleye, Sander vitreus, Index Netting Survey, 2004; Data Report

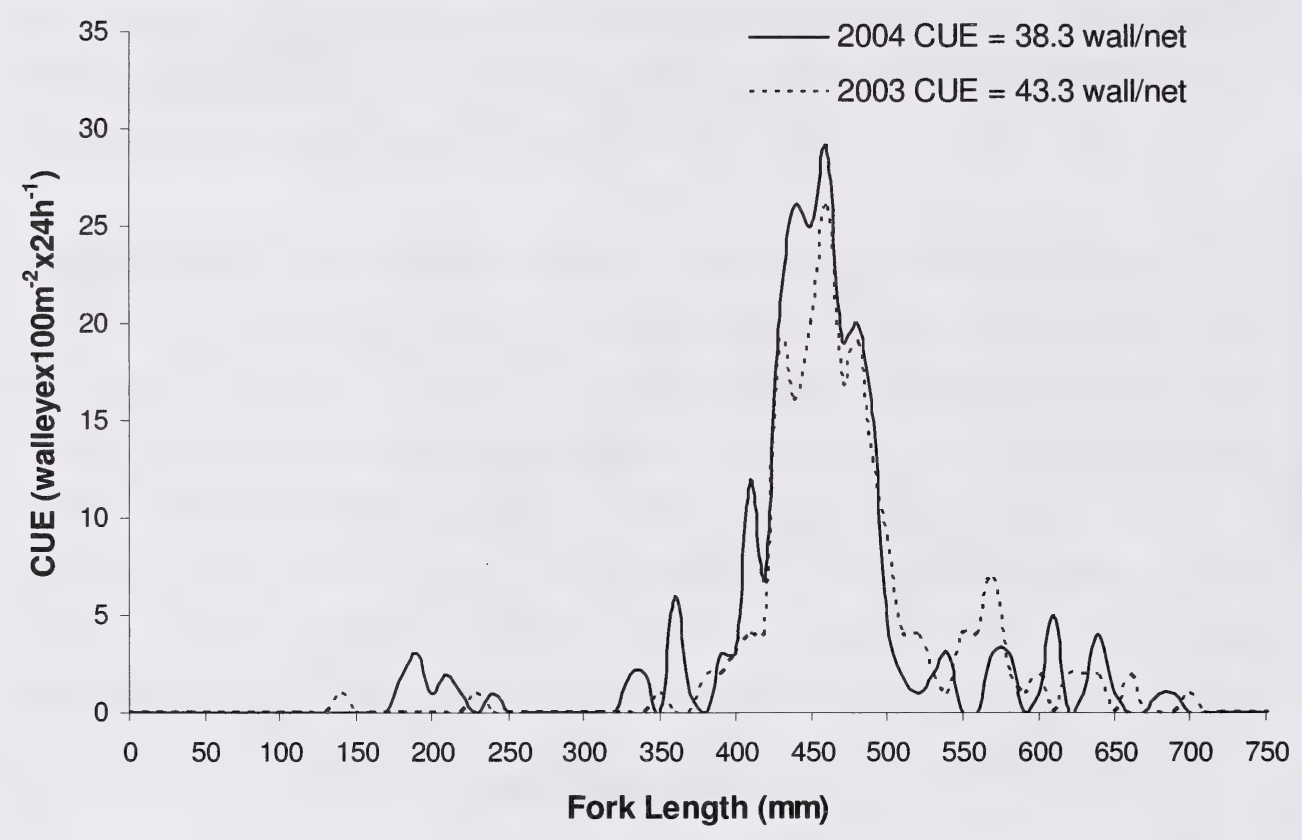

Figure 4. Walleye Fork Length Frequency Distribution, Pigeon Lake, 2003-04; (2004 mean fork length $=449 \mathrm{~mm}$, mean CUE $=29$ ). 
Pigeon Lake Fall Walleye, Sander vitreus, Index Netting Survey, 2004: Data Report

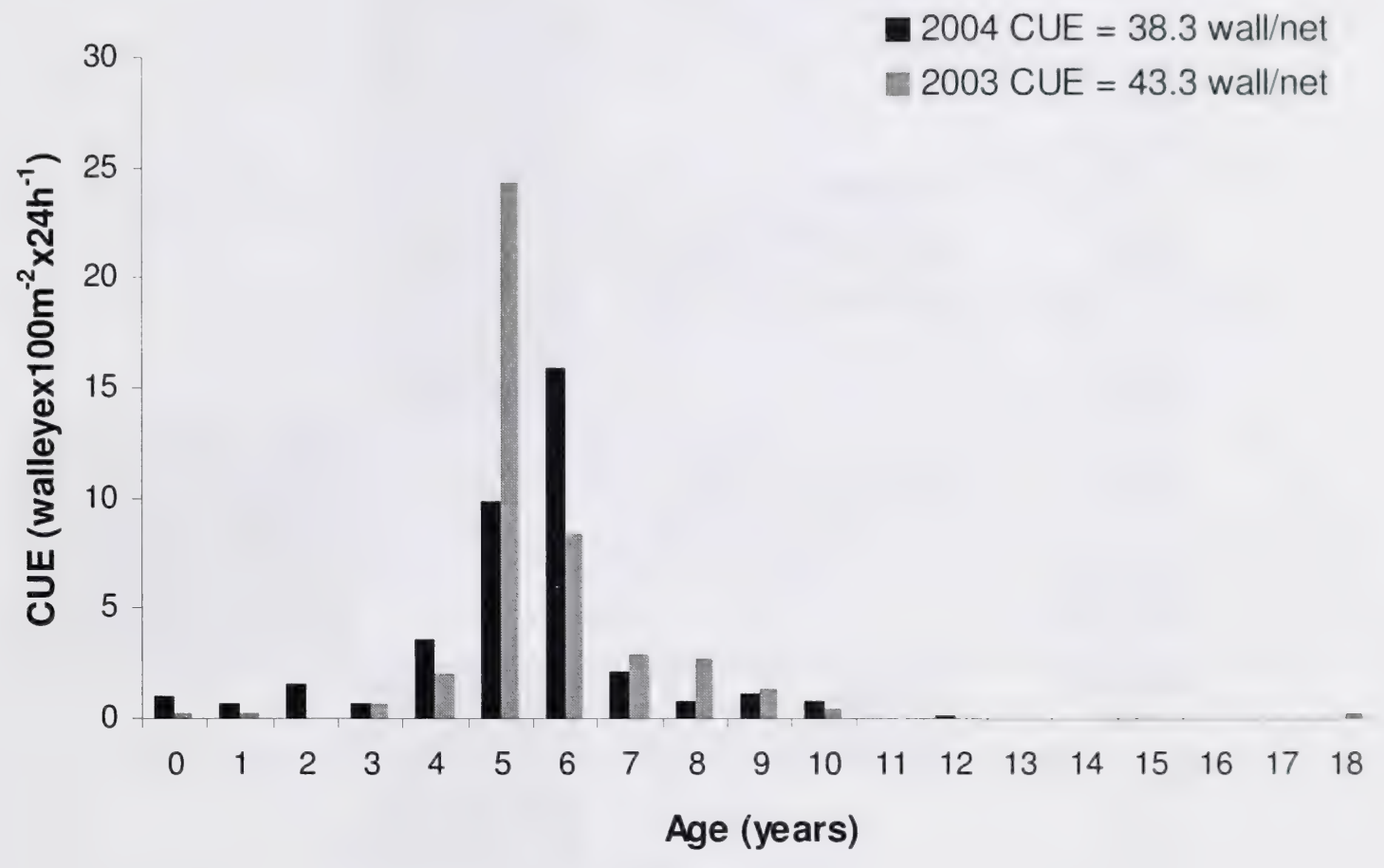

Figure 5. Walleye age-class frequency distribution, Pigeon Lake, 2003-2004. 
Pigeon Lake Fall Walleye, Sander vitreus, Index Netting Survey, 2004; Data Report

Table 1. Criteria for classifying status of walleye fisheries, modified for FWIN analysis (from Sullivan, 2003)

\begin{tabular}{|c|c|c|c|c|}
\hline STATUS OF STOCK & TROPHY & STABLE & VULNERABLE & COLLAPSED \\
\hline $\begin{array}{l}\text { Age-class } \\
\text { Distribution }\end{array}$ & $\begin{array}{c}\text { Wide } \\
8 \text { or more age } \\
\text { classes } \\
\text { mean age }>9\end{array}$ & $\begin{array}{c}\text { Wide } \\
8 \text { or more age } \\
\text { classes } \\
\text { mean age }=6-9\end{array}$ & $\begin{array}{c}\text { Narrow } \\
1-3 \text { age classes } \\
\text { mean age }=4-6 \\
\text { few old ( }>10 \text { years) } \\
\text { fish }\end{array}$ & $\begin{array}{c}\text { Wide or Narrow } \\
\text { Mean age }=6-10\end{array}$ \\
\hline $\begin{array}{l}\text { Pigeon Lake } \\
2004 \\
\text { Pigeon Lake } \\
2003 \\
\end{array}$ & & & $\begin{array}{c}2 \text { age-classes } \\
\text { mean age }=5.4 \\
2 \text { age classes } \\
\text { mean age }=5.6\end{array}$ & \\
\hline $\begin{array}{l}\text { Age-class } \\
\text { Stability }\end{array}$ & $\begin{array}{c}\text { Very Stable } \\
1 \text { - } 2 \text { age classes } \\
\text { out of smooth } \\
\text { catch curve }\end{array}$ & $\begin{array}{c}\text { Relatively Stable } \\
2 \text { - } 3 \text { age classes } \\
\text { out of smooth } \\
\text { catch curve }\end{array}$ & $\begin{array}{c}\text { Unstable } \\
1-3 \text { age classes } \\
\text { support fishery }\end{array}$ & $\begin{array}{l}\text { Stable or Unstable } \\
\text { Recruitment failures }\end{array}$ \\
\hline $\begin{array}{l}\text { Pigeon Lake } \\
2004 \\
\text { Pigeon Lake } \\
2003\end{array}$ & & & $\begin{array}{l}2 \text { age-classes } \\
2 \text { age-classes }\end{array}$ & \\
\hline $\begin{array}{l}\text { Age-at- } \\
\text { Maturity }\end{array}$ & $\begin{array}{c}\text { Females } 10-20 \\
\text { Males } 10-16\end{array}$ & $\begin{array}{c}\text { Females } 8 \text { - } 10 \\
\text { Males } 7 \text { - } 9\end{array}$ & $\begin{array}{c}\text { Females } 7-8 \\
\text { Males } 5-7\end{array}$ & $\begin{array}{c}\text { Females } 4-7 \\
\text { Males } 3-6 \\
\text { Ages will vary with } \\
\text { age class distribution }\end{array}$ \\
\hline $\begin{array}{l}\text { Pigeon Lake } \\
2004 \\
\text { Pigeon Lake } \\
2003\end{array}$ & & & & $\begin{array}{c}\text { Females at } 6.2 \\
\text { Males at } 5.5 \\
\text { Females at } 5.8 \\
\text { Males at } 5.7\end{array}$ \\
\hline $\begin{array}{l}\text { Length-at- } \\
\text { Age }\end{array}$ & $\begin{array}{c}\text { Very slow } \\
50 \mathrm{~cm}(\mathrm{TL}) \text { in } \\
12-15 \text { years }\end{array}$ & $\begin{array}{c}\text { Slow } \\
50 \mathrm{~cm}(\mathrm{TL}) \text { in } \\
9-12 \text { years }\end{array}$ & $\begin{array}{l}\text { Moderate } \\
50 \mathrm{~cm}(\mathrm{TL}) \text { in } \\
7-9 \text { years }\end{array}$ & $\begin{array}{c}\text { Fast } \\
50 \mathrm{~cm}(\mathrm{TL}) \text { in } \\
4-7 \text { years }\end{array}$ \\
\hline $\begin{array}{l}\text { Pigeon Lake } \\
2004 \\
\text { Pigeon Lake } \\
2003\end{array}$ & & & $\begin{array}{l}50 \mathrm{~cm} \mathrm{TL} \\
\text { in } 7 \text { years } \\
50 \mathrm{~cm} \mathrm{TL} \\
\text { in } 7 \text { years }\end{array}$ & \\
\hline $\begin{array}{c}\text { Catch Rate } \\
\text { FWIN }\end{array}$ & & $\begin{array}{c}\text { High }>30 \\
\text { walleye / net }\end{array}$ & $\begin{array}{c}\text { Moderate } 5-25 \\
\text { walleye / net }\end{array}$ & $\begin{array}{c}\text { Low }<5 \\
\text { walleye / net }\end{array}$ \\
\hline $\begin{array}{l}\text { Pigeon Lake } \\
2004 \\
\text { Pigeon Lake } \\
2003\end{array}$ & & $\begin{array}{c}38.3 \\
\text { walleyes/net } \\
43.3 \\
\text { walleyes/net }\end{array}$ & & \\
\hline
\end{tabular}


Pigeon Lake Fall Walleye, Sander vitreus, Index Netting Survey, 2004: Data Report 
Pigeon Lake Fall Walleye, Sander vitreus, Index Netting Survey, 2004; Data Report
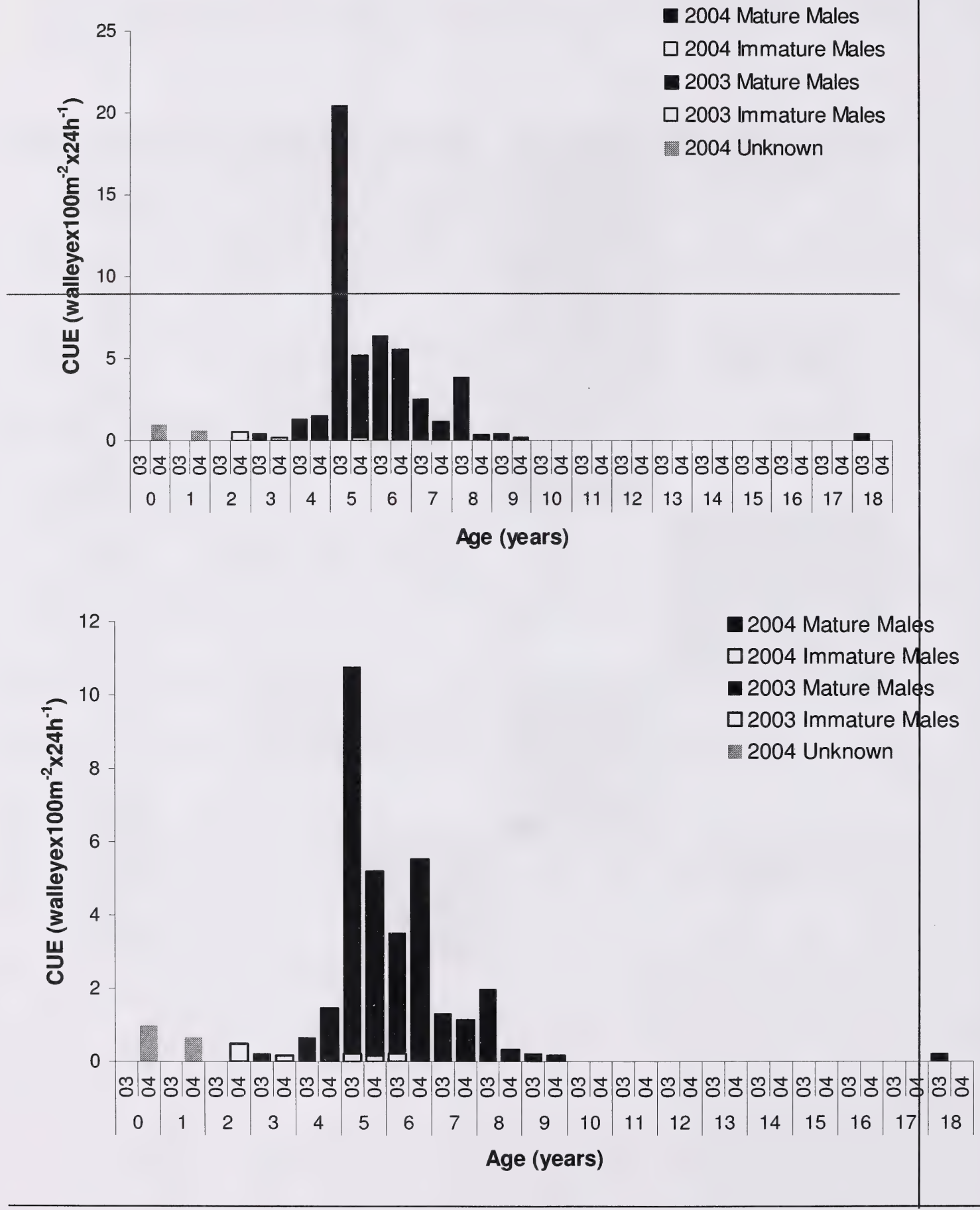
Pigeon Lake Fall Walleye, Sander vitreus, Index Netting Survey, 2004: Data Report

Figure 6. Age-at-maturity of male walleyes, Pigeon Lake, 2003-2004.

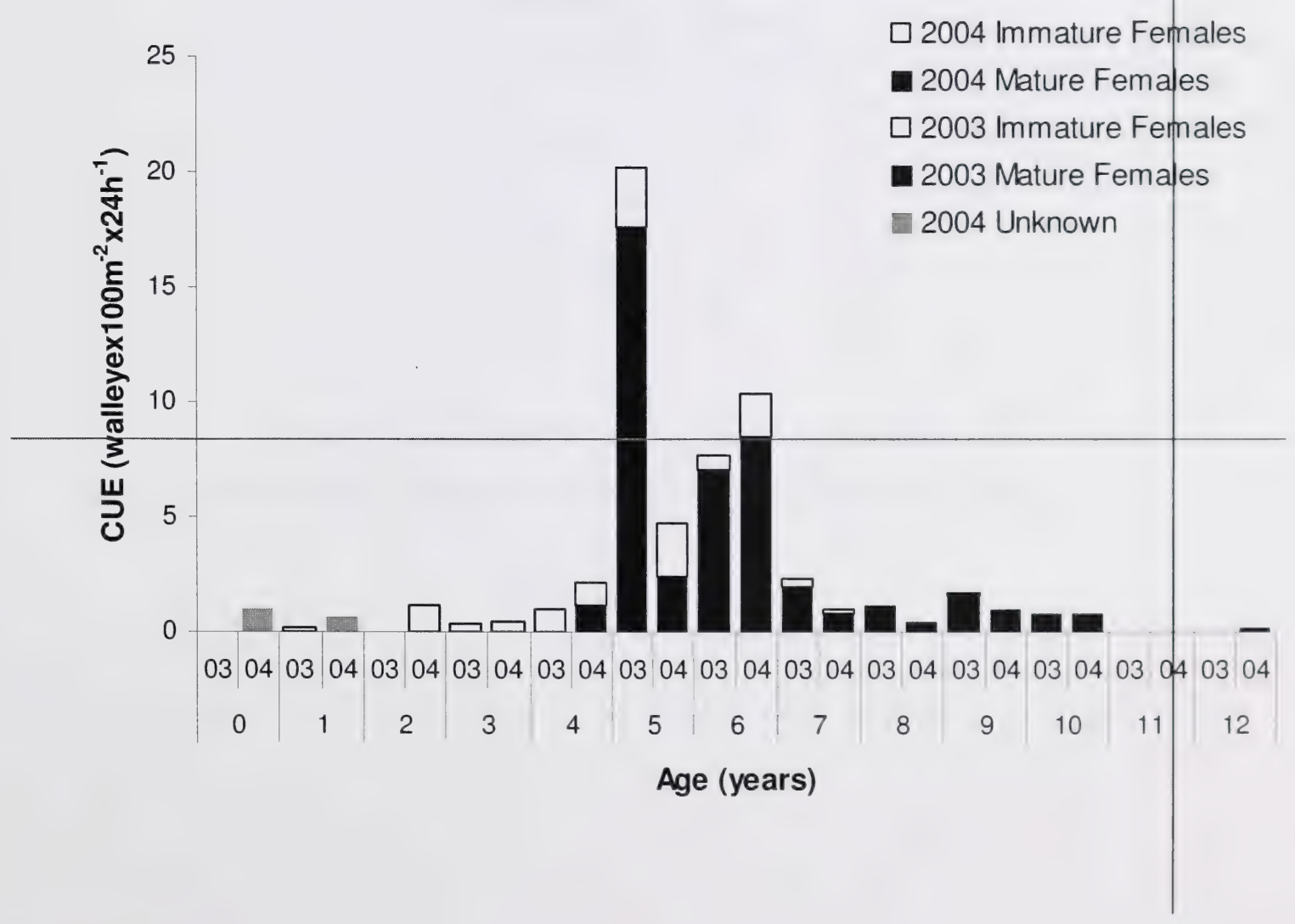


Pigeon Lake Fall Walleye, Sander vitreus, Index Netting Survey, 2004; Data Report

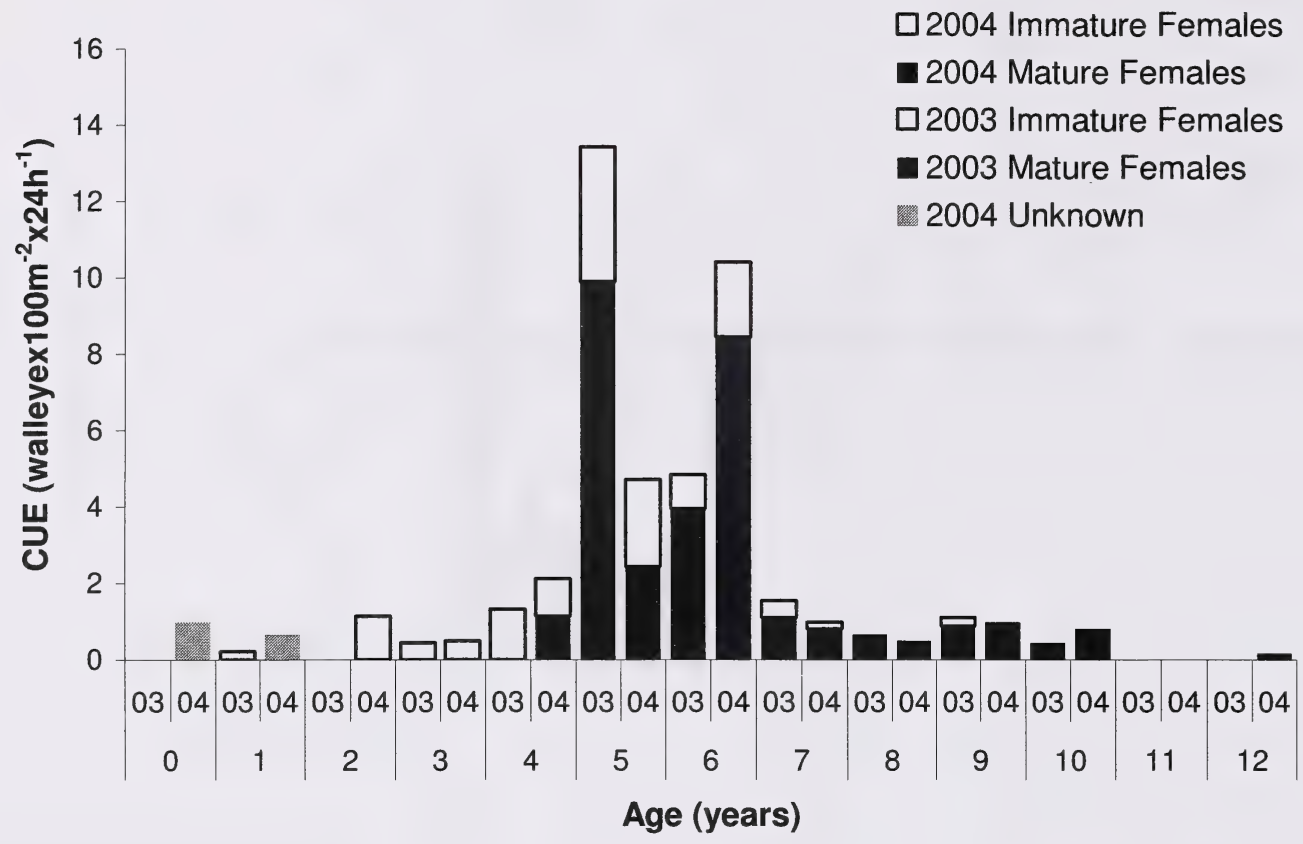

Figure 7. Age-at-maturity of female walleyes, Pigeon Lake, 2003-2004. 
Pigeon Lake Fall Walleye, Sander vitreus, Index Netting Survey, 2004; Data Report

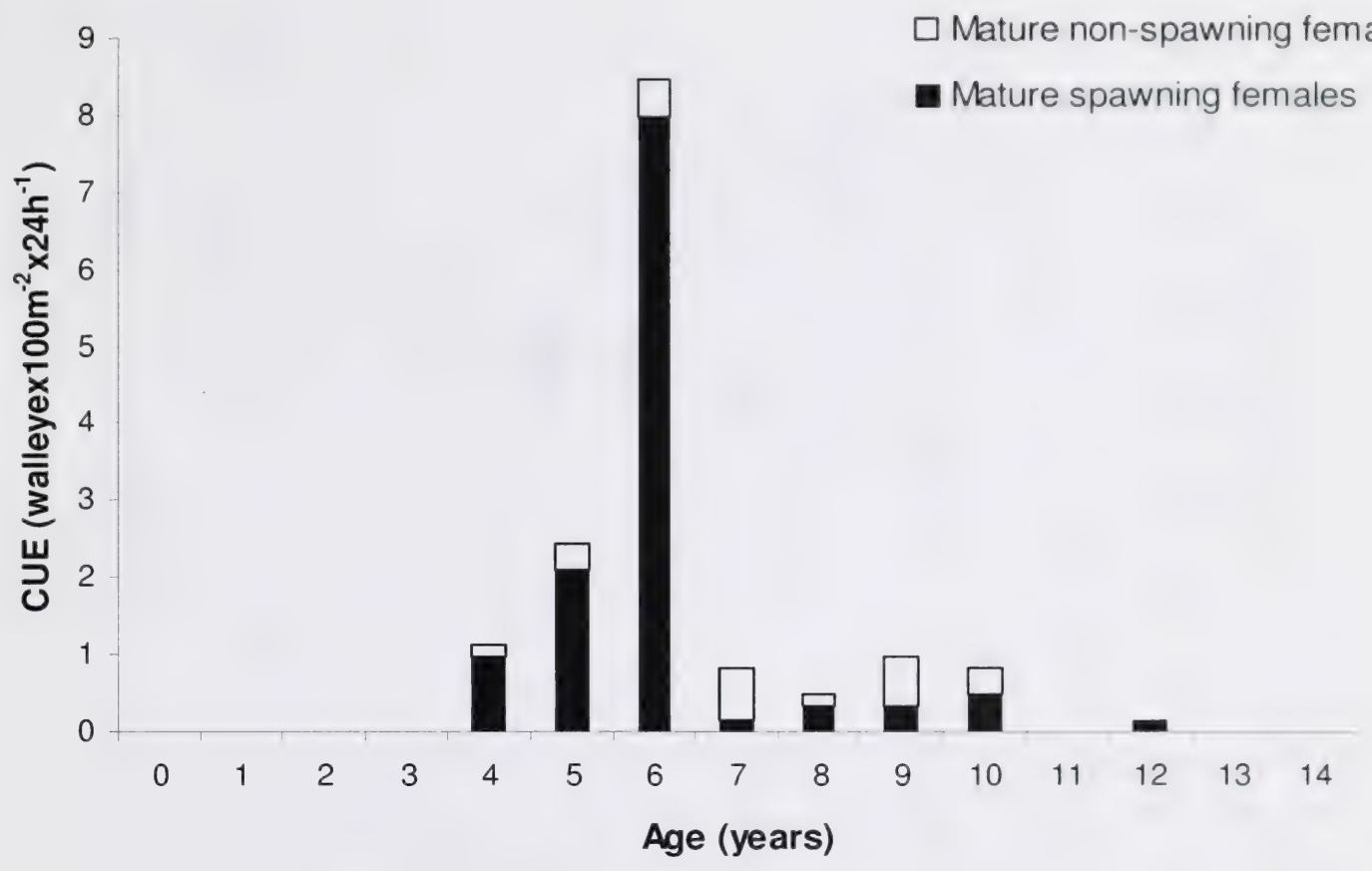

Figure 8. Age-at-maturity of non-spawning female walleyes, Pigeon Lake, 2004. 
Pigeon Lake Fall Walleye, Sander vitreus, Index Netting Survey, 2004; Data Report

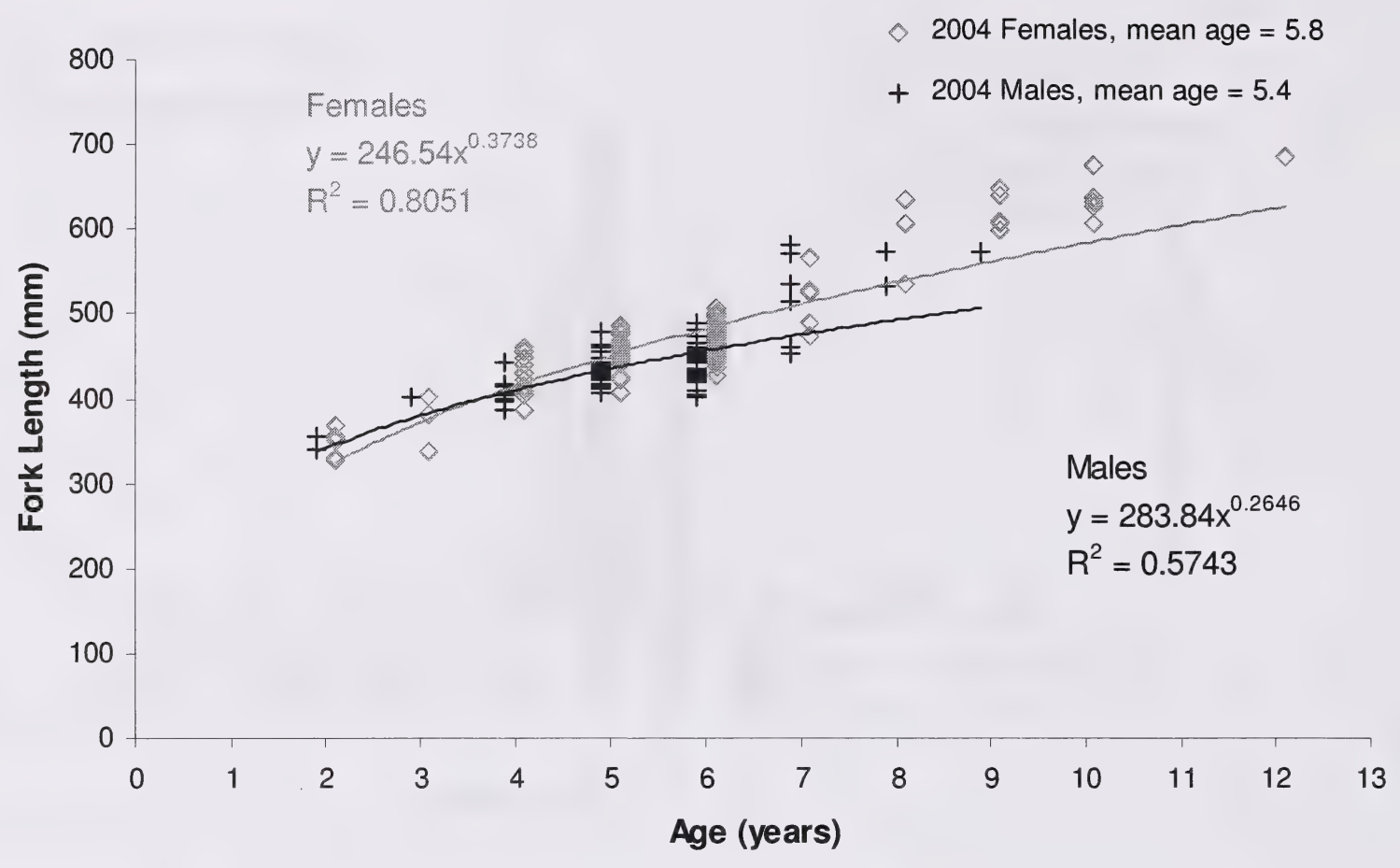

Figure 9 . Length-at-age (logarithmic line-of-best-fit) of male and female walleyes, Pigeon Lake, 2004.

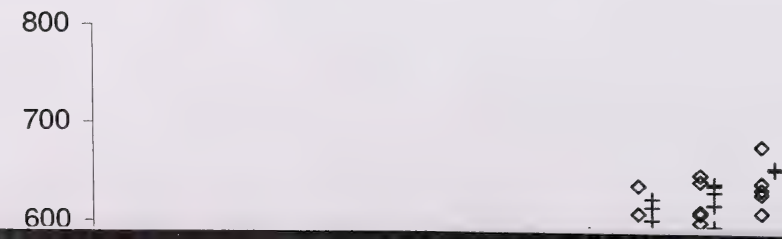


Pigeon Lake Fall Walleye, Sander vitreus, Index Netting Survey. 2004: Data Report

Figure 10. Walleye length-at-age comparisons for Pigeon Lake, 2003-2004 
Pigeon Lake Fall Walleye, Sander vitreus, Index Netting Survey, 2004; Data Report

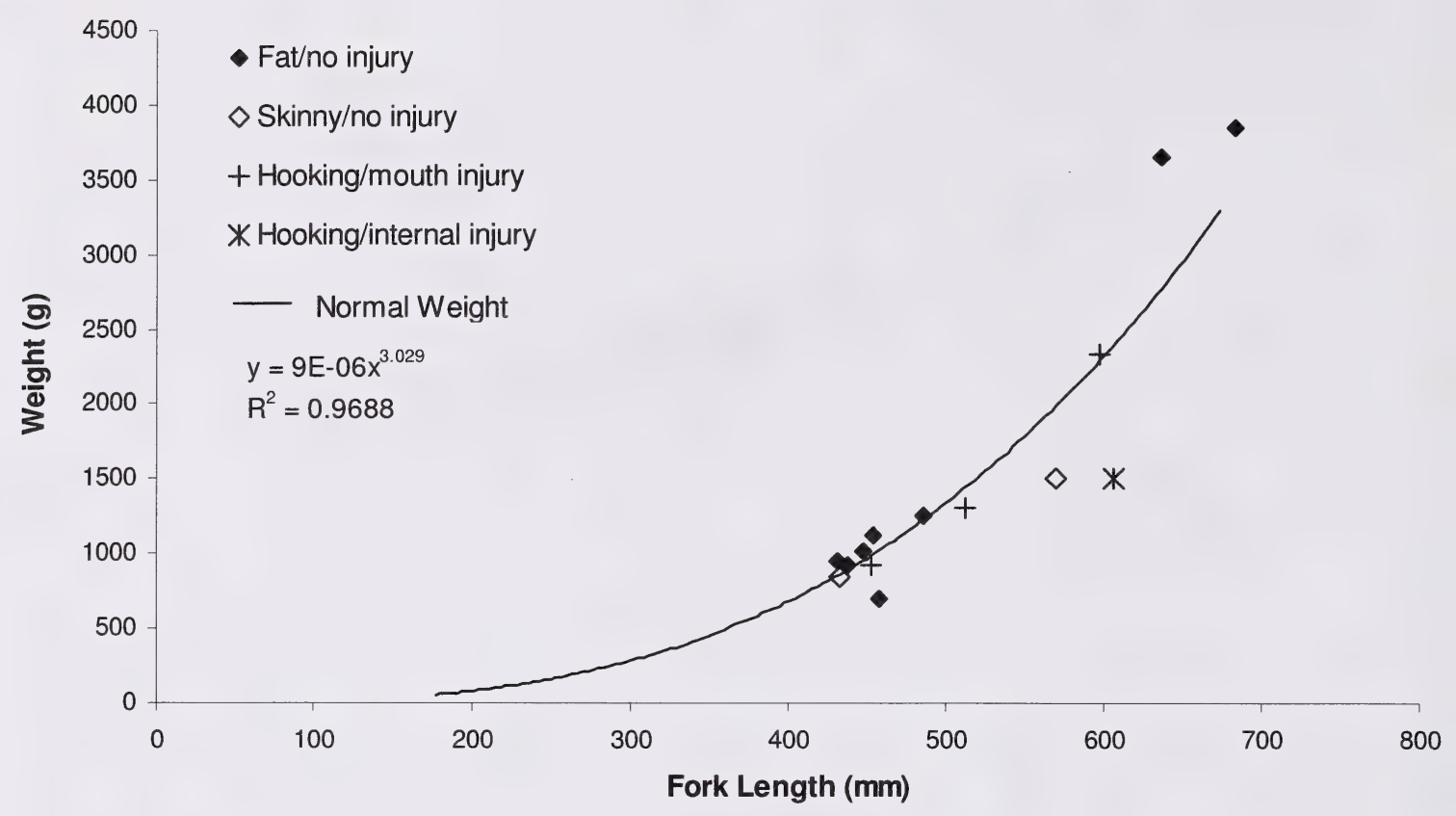

Figure 11. Length-at-weight visual assessment including physical and injury conditions, Pigeon Lake, 2004. 
Pigeon Lake Fall Walleye, Sander vitreus, Index Netting Survey, 2004; Data Report

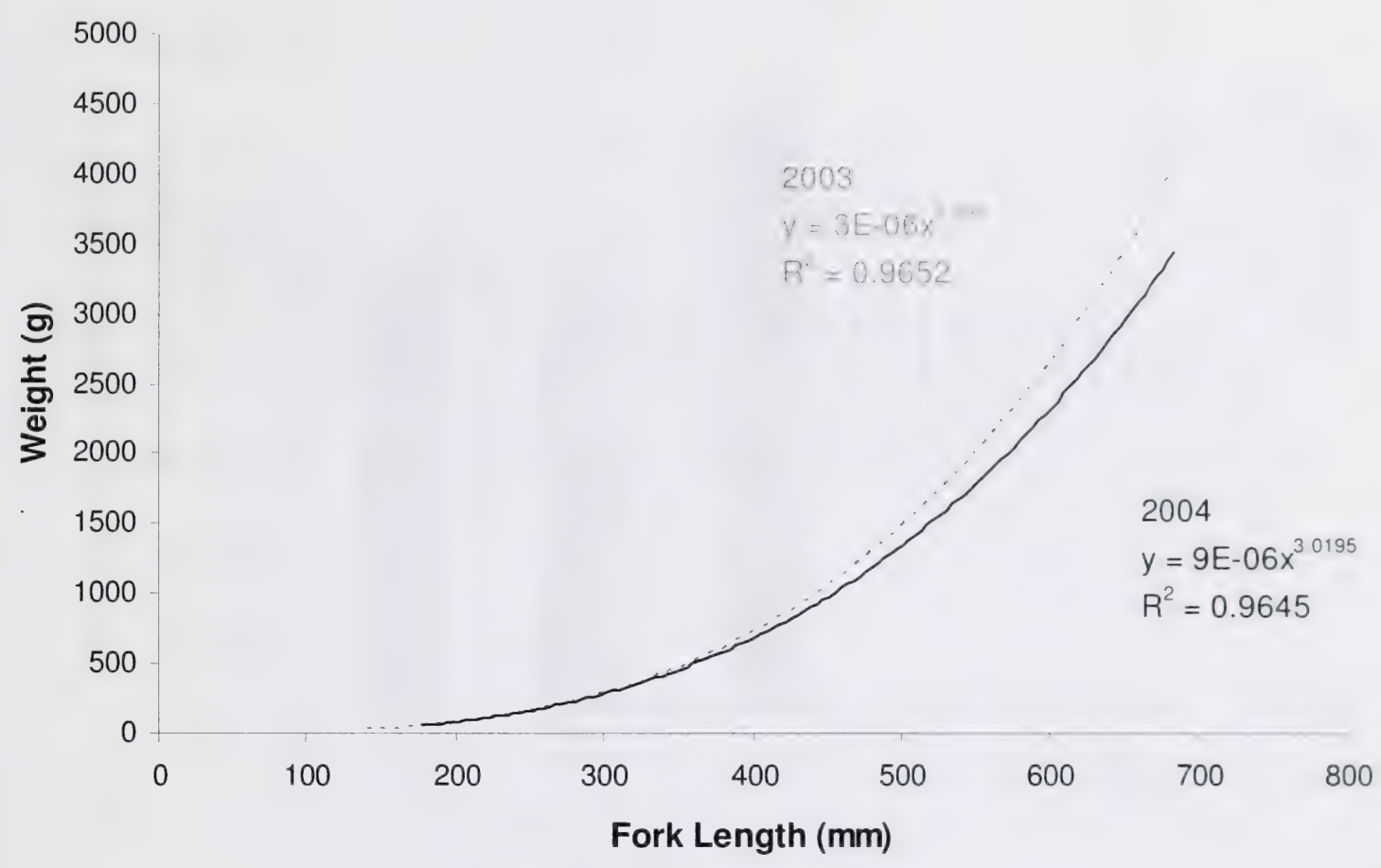

Figure 12. Walleye length-at-weight, Pigeon Lake, 2003-2004 
Pigeon Lake Fall Walleye, Sander vitreus, Index Netting Survey, 2004; Data Report

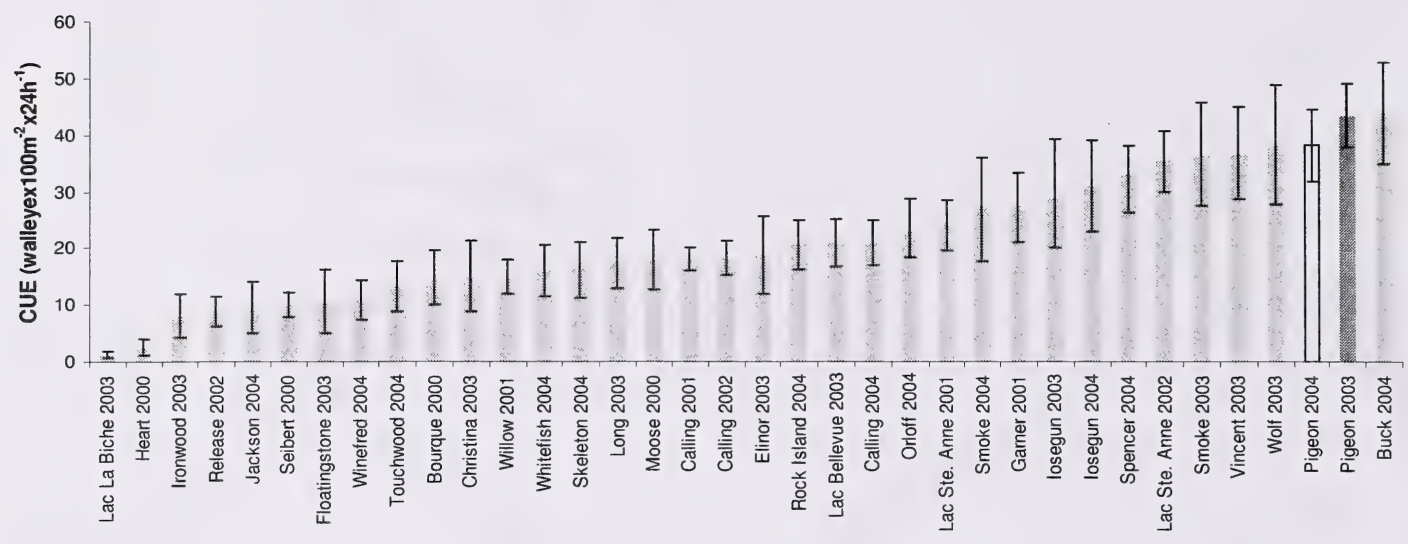

Figure 13. FWIN catches of walleyes from 30 Alberta lakes from 2000-2004. Error bars depict 95\% confidence intervals, CUE's range from 1.3-43.9. 
Pigeon Lake Fall Walleye, Sander vitreus, Index Netting Survey, 2004; Data Report

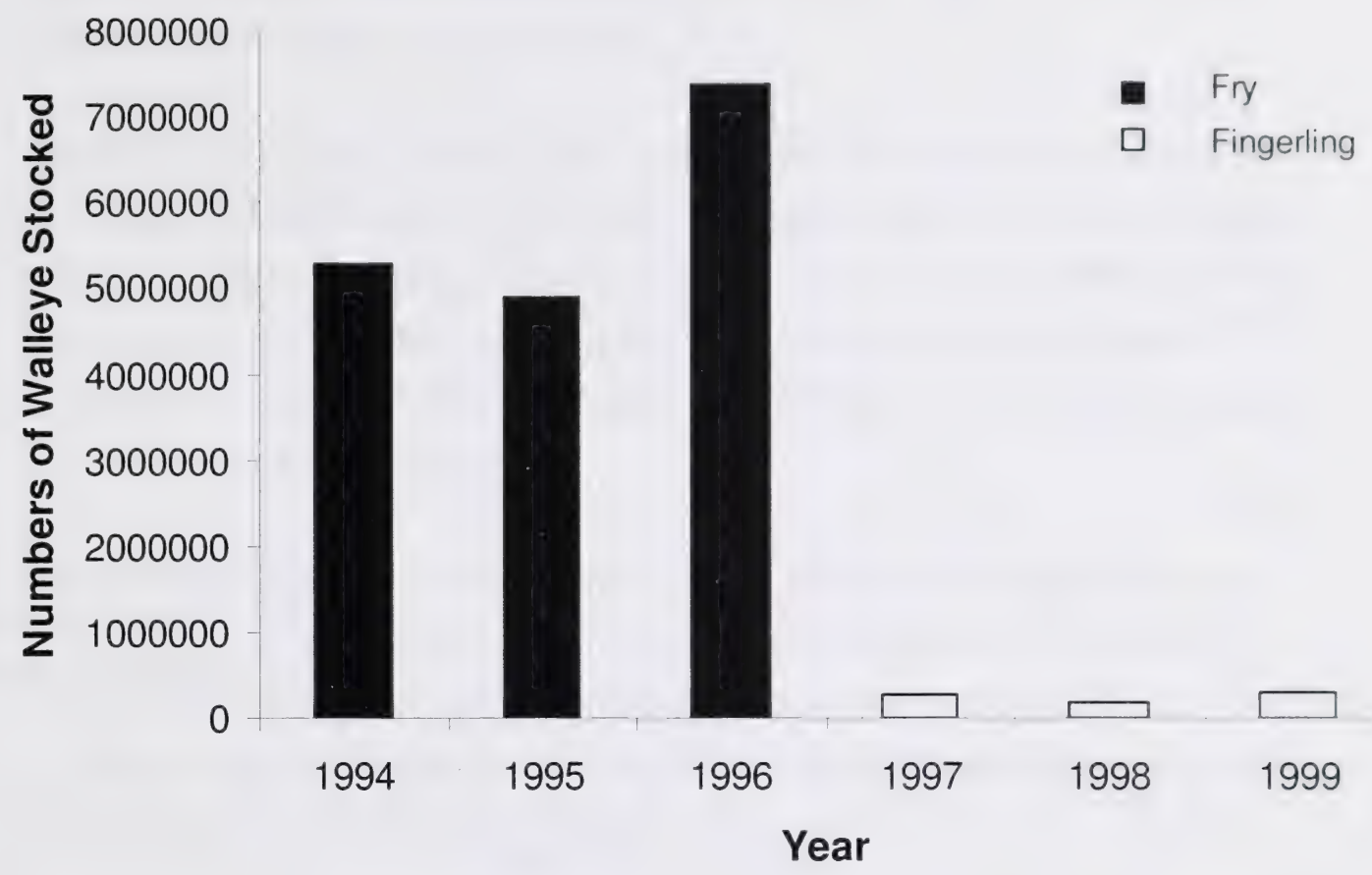

Figure 14. Stocked young-of-the-year walleyes, Pigeon Lake, 1994-1999. 


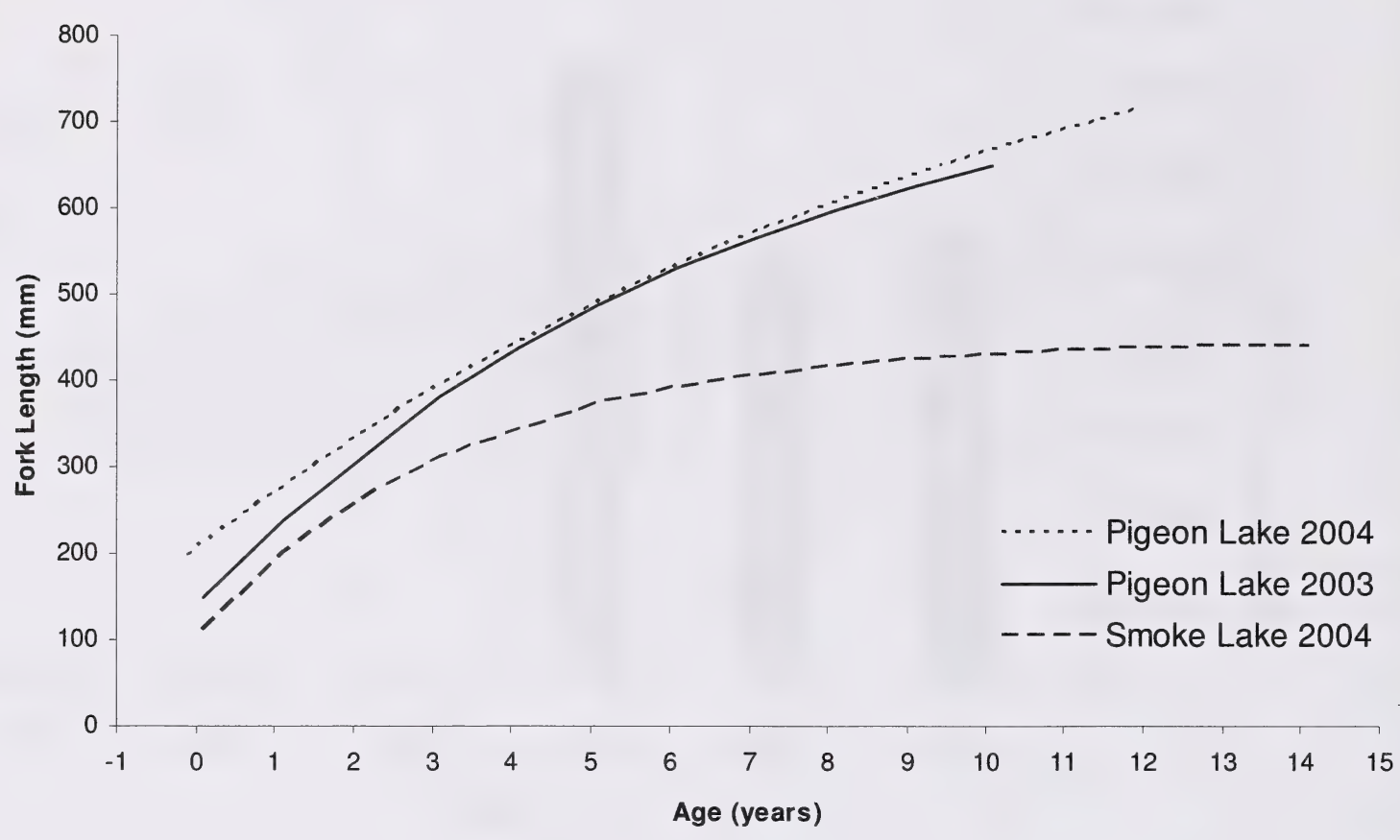

Figure 15. Von Bertalanffy growth curves and parameters fitted to observed fork lengthat-age data for Pigeon Lake, 2003; $\mathrm{k}=0.148, \mathrm{t}_{0}=-1.387, \mathrm{~L}_{\infty}=795 \mathrm{~mm}$ FL, Pigeon Lake, 2004; $\mathrm{k}=0.092, \mathrm{t}_{0}=-2.487, \mathrm{~L}_{\infty}=968 \mathrm{~mm}$ FL, Smoke Lake, 2004; $\mathrm{k}=0.301, \mathrm{t}_{0}=-0.96$, $\mathrm{L}_{\infty}=447 \mathrm{~mm}$ FL.

\subsection{SUMMARY}

According to the ASRD Walleye Management and Recovery Plan (Berry 1995) the management status of the walleye population in 2004 is vulnerable and unchanged from 2003. Of the 5 biological characteristics of the walleye population, 3 characteristics 
Pigeon Lake Fall Walleye, Sander vitreus, Index Netting Survey, 2004: Data Report

indicate a vulnerable population, 1 characteristic indicates a collapsed population and 1 characteristic indicates a stable population.

Both Pigeon Lake 2003 and 2004 FWIN surveys revealed low recruitment and few old walleyes. The 2003 FWIN caught 1 young-of-the-year walleye; and in 20046 young-ofthe-year walleyes were caught. There was only 1 old-growth walleye caught in 2003 and no walleyes older than 10 in 2004. We note that old-growth walleyes in Canada have been aged in excess of 39 years old (Susan Mann, Northwest Science and Information. Dryden, personal communication).

Some Pigeon Lake anglers have the perception that the walleye in Pigeon Lake are 'skinny' due to repetitive catch. Few of the walleye sampled had hooking damage and there appeared to be no correlation between hooking damage and fish condition. In 2004. walleye weighted less than fish of the same length in 2003 . These differences between years were more pronounced in the larger fish.

Two age-classes support the fishery in both the 2003 and 2004 FWIN samples. This situation indicates a narrow year class distribution with weak recruitment (or stocking) classes. The two age-classes make-up $67 \%$ of the 2004 sample.

\subsection{LITERATURE CITED}

Berry, D.K. 1995. Alberta's Walleye Management and Recovery Plan. Alberta Environment Protection, Natural Resources Service. Number T/310. 32 pp. 
Pigeon Lake Fall Walleye, Sander vitreus, Index Netting Survey, 2004; Data Report

Campana, S.E. 2001. Accuracy, precision and quality control in age determination, including review of the use and abuse of age validation methods. Journal of Fish Biology 59, 197-242.

Casselman, J. M. 1995. Otolith techniques for identifying and discriminating between pond-cultured and indigenous walleye Stizostedion vitreum from the natural environment. Ontario Ministry of Natural Resources, Glenora Fisheries Station, Glenora.

Mackay, W.C., G.R. Ash, and H.J. Norris (eds.). 1990. Fish ageing methods for Alberta. R.L. \& L. Environmental Services Ltd. In assoc. with Alberta Fish and Wildl. Div. and Univ. of Alberta, Edmonton. 113 pp.

Mitchell, P. and E. Prepas. 1990. Atlas of Alberta Lakes. University of Alberta Press, Edmonton. 675 pp.

Morgan, G.E. 2000. Manual of Instructions, Fall Walleye Index Netting (FWIN). Ontario Ministry of Natural Resources. Fish and Wildlife Branch. 37 pp.

Patterson, B. 2004. Assesment of the summer sport fishery for walleye and northern pike at Pigeon Lake, 2003. Produced by Alberta Conservation Association Edmonton, Alberta, Canada. 55p

Slipke, J. and M. Maceina. 2001. Fishery analyses and simulations tools (FAST), version 2.1. Auburn University, Department of Fisheries and Allied Aquacultures, Auburn, Alabama, USA. 156pp.

Sullivan, M.G. 2003. Active management of walleye fisheries in Alberta: dilemmas of managing recovering fisheries. North America Journal of Fisheries Management 23(4): in press 
Pigeon Lake Fall Walleye, Sander vitreus, Index Netting Survey, 2004: Data Report

\subsection{APPENDICES}

Appendix 6.1. Catch Composition from FWIN Nets, Pigeon Lake, 2004.

\begin{tabular}{|l|c|c|c|c|c|c|c|c|c|c|c|}
\hline Set \# & Depth $(\mathrm{m})$ & Temp. & Soak & \multicolumn{9}{|c|}{ Species } \\
\cline { 5 - 12 } & $\min / \max$ & $\left({ }^{\circ} \mathrm{C}\right)$ & Time $(\mathrm{h})$ & WALL & NRPK & YLPR & LKWH & WHSC & TRPR & SPSH & Total \\
\hline 1 & $5.4-5.7$ & 10 & 21.82 & 30 & 3 & 2 & 13 & 0 & 0 & 1 & 49 \\
2 & $4.3-4.7$ & 10 & 23.15 & 48 & 2 & 0 & 14 & 0 & 0 & 0 & 64 \\
3 & $7.0-8.0$ & 10 & 23.60 & 29 & 1 & 1 & 10 & 0 & 1 & 2 & 44 \\
4 & $4.3-4.9$ & 10 & 22.33 & 45 & 2 & 0 & 9 & 0 & 0 & 0 & 56
\end{tabular}


Pigeon Lake Fall Walleye, Sander vitreus, Index Netting Survey, 2004; Data Report

\begin{tabular}{|c|c|c|c|c|c|c|c|c|c|c|c|}
5 & $3.1-4.0$ & 10 & 21.50 & 35 & 1 & 0 & 16 & 0 & 1 & 0 & 53 \\
6 & $4.0-4.0$ & 10 & 22.33 & 49 & 3 & 0 & 7 & 0 & 0 & 0 & 59 \\
\hline Total \\
\hline
\end{tabular}

Appendix 6.2. Walleye, northern pike, yellow perch, and lake whitefish catches by mesh size, Pigeon Lake 2004. 
Pigeon Lake Fall Walleye, Sander vitreus, Index Netting Survey, 2004; Data Report

\begin{tabular}{|c|c|c|c|c|c|c|c|c|c|c|c|c|}
\hline \multicolumn{13}{|l|}{ WALL } \\
\hline Set \# & $\begin{array}{l}\text { Depth } \\
\text { (m) }\end{array}$ & Easting & Northing & \multicolumn{9}{|c|}{ Mesh Size (mm) } \\
\hline & & & & 25 & 38 & 51 & 64 & 76 & 102 & 127 & 152 & Total \\
\hline 1 & 5.6 & 298690.00 & 5873888.00 & 1 & 4 & 4 & 4 & 5 & 9 & 1 & 2 & 30 \\
\hline 2 & 4.5 & 694311.00 & 5877683.00 & 2 & 6 & 3 & 12 & 11 & 10 & 3 & 1 & 48 \\
\hline 3 & 7.5 & 695522.00 & 5880255.00 & 0 & 2 & 2 & 4 & 11 & 7 & 3 & 0 & 29 \\
\hline 4 & 4.6 & 299020.00 & 5880800.00 & 2 & 5 & 8 & 10 & 8 & 10 & 2 & 0 & 45 \\
\hline 5 & 3.6 & 300580.00 & 5874840.00 & 1 & 6 & 2 & 11 & 8 & 6 & 0 & 1 & 35 \\
\hline 6 & 4.0 & 299020.00 & 5881050.00 & 2 & 9 & 8 & 15 & 7 & 6 & 1 & 1 & 49 \\
\hline Total & & & & 8 & 32 & 27 & 56 & 50 & 48 & 10 & 5 & 236 \\
\hline CUE & & & & 1.3 & 5.3 & 4.5 & 9.3 & 8.3 & 8.0 & 1.7 & 0.8 & 39.3 \\
\hline
\end{tabular}

\begin{tabular}{|c|c|c|c|c|c|c|c|c|c|c|c|c|}
\hline \multicolumn{13}{|l|}{ NRPK } \\
\hline Set \# & $\begin{array}{l}\text { Depth } \\
\text { (m) }\end{array}$ & Easting & Northing & \multicolumn{9}{|c|}{ Mesh Size $(\mathrm{mm})$} \\
\hline & & & & 25 & 38 & 51 & 64 & 76 & 102 & 127 & 152 & Total \\
\hline 1 & 5.6 & 298690.00 & 5873888.00 & 0 & 0 & 1 & 1 & 0 & 0 & 1 & 0 & 3 \\
\hline 2 & 4.5 & 694311.00 & 5877683.00 & 0 & 0 & 1 & 0 & 0 & 0 & 1 & 0 & 2 \\
\hline 3 & 7.5 & 695522.00 & 5880255.00 & 0 & 0 & 0 & 1 & 0 & 0 & 0 & 0 & 1 \\
\hline 4 & 4.6 & 299020.00 & 5880800.00 & 0 & 0 & 1 & 1 & 0 & 0 & 0 & 0 & 2 \\
\hline 5 & 3.6 & 300580.00 & 5874840.00 & 0 & 0 & 0 & 0 & 0 & 0 & 1 & 0 & 1 \\
\hline 6 & 4.0 & 299020.00 & 5881050.00 & 0 & 0 & 2 & 0 & 1 & 0 & 0 & 0 & 3 \\
\hline Total & & & & 0 & 0 & 5 & 3 & 1 & 0 & 3 & 0 & 12 \\
\hline CUE & & & & 0.0 & 0.0 & 0.83 & 0.50 & 0.17 & 0.0 & 0.50 & 0.0 & 2.0 \\
\hline
\end{tabular}

\begin{tabular}{|c|c|c|c|c|c|c|c|c|c|c|c|c|}
\hline \multicolumn{13}{|l|}{ YLPR } \\
\hline Set \# & $\begin{array}{c}\text { Depth } \\
(\mathrm{m})\end{array}$ & Easting & Northing & \multicolumn{9}{|c|}{ Mesh Size (mm) } \\
\hline & & & & 25 & 38 & 51 & 64 & 76 & 102 & 127 & 152 & Total \\
\hline 1 & 5.6 & 298690.00 & 5873888.00 & 1 & 1 & 0 & 0 & 0 & 0 & 0 & 0 & 2 \\
\hline 2 & 4.5 & 694311.00 & 5876830.00 & 0 & 0 & 0 & 0 & 0 & 0 & 0 & 0 & 0 \\
\hline 3 & 7.5 & 695522.00 & 5880255.00 & 1 & 0 & 0 & 0 & 0 & 0 & 0 & 0 & 1 \\
\hline 4 & 4.6 & 299020.00 & 5880800.00 & 0 & 0 & 0 & 0 & 0 & 0 & 0 & 0 & 0 \\
\hline 5 & 3.6 & 300580.00 & 5874840.00 & 0 & 0 & 0 & 0 & 0 & 0 & 0 & 0 & 0 \\
\hline 6 & 4.0 & 299020.00 & 5881050.00 & 0 & 0 & 0 & 0 & 0 & 0 & 0 & 0 & 0 \\
\hline Total & & & & 2 & 1 & 0 & 0 & 0 & 0 & 0 & 0 & 3 \\
\hline CUE & & & & 0.333 & 0.167 & 0.000 & 0.000 & 0.000 & 0.000 & 0.000 & 0.000 & 0.500 \\
\hline
\end{tabular}

Appendix 6.2 continued. 
Pigeon Lake Fall Walleye, Sander vitreus, Index Netting Survey, 2004; Data Report

\begin{tabular}{|c|c|c|c|c|c|c|c|c|c|c|c|c|}
\hline \multicolumn{13}{|c|}{ LKWH } \\
\hline Set \# & $\begin{array}{c}\text { Depth } \\
\text { (m) }\end{array}$ & Easting & Northing & \multicolumn{9}{|c|}{ Mesh Size (mm) } \\
\hline & & & & 25 & 38 & 51 & 64 & 76 & 102 & 127 & 152 & Total \\
\hline 1 & 5.6 & 298690.00 & 5873888.00 & 0 & 4 & 1 & 2 & 0 & 5 & 1 & 0 & 13 \\
\hline 2 & 4.5 & 694311.00 & 5876830.00 & 0 & 1 & 1 & 3 & 4 & 3 & 2 & 0 & 14 \\
\hline 3 & 7.5 & 695522.00 & 5880255.00 & 0 & 1 & 1 & 2 & 2 & 4 & 0 & 0 & 10 \\
\hline 4 & 4.6 & 299020.00 & 5880800.00 & 0 & 1 & 0 & 3 & 3 & 1 & 1 & 0 & 9 \\
\hline 5 & 3.6 & 300580.00 & 5874840.00 & 0 & 1 & 1 & 2 & 5 & 4 & 2 & 1 & 16 \\
\hline 6 & 4.0 & 299020.00 & 5881050.00 & 0 & 0 & 0 & 0 & 2 & 5 & 0 & 0 & 7 \\
\hline Total & & & & 0 & 8 & 4 & 12 & 16 & 22 & 6 & 1 & 69 \\
\hline CUE & & & & 0 & 1.3 & 0.7 & 2.0 & 2.7 & 3.7 & 1.0 & 0.17 & 11.5 \\
\hline
\end{tabular}

Appendix 6.3. Statistics of the catch distribution for game fish catches, Pigeon Lake, 2004. This data is for presentation of the statistical nature of the catch distribution and are based on the geometric mean values (unweighted). 
Pigeon Lake Fall Walleye, Sander vitreus, Index Netting Survey, 2004: Data Report

\begin{tabular}{|l|r|}
\hline \multicolumn{2}{|c|}{ Walleye 2004 } \\
\hline Mean (fish/net) & 39.3 \\
\hline Relative Standard Error (\%) & 9.44 \\
\hline Standard Error & 3.7 \\
\hline Median & 40 \\
\hline Mode & \#N/A \\
\hline Standard Deviation & 9.09 \\
\hline Sample Variance & 82.67 \\
\hline Kurtosis & -2.691 \\
\hline Skewness & -0.104 \\
\hline Range & 20 \\
\hline Minimum & 29 \\
\hline Maximum & 49 \\
\hline Sum & 236 \\
\hline Count (nets) & 6 \\
\hline Confidence Level (95.0\%) & 9.54 \\
\hline
\end{tabular}

\begin{tabular}{|l|r|}
\hline \multicolumn{2}{|c|}{ Northern Pike 2004 } \\
\hline Mean (fish/net) & 2.0 \\
\hline Relative Standard Error (\%) & 18.26 \\
\hline Standard Error & 0.4 \\
\hline Median & 2 \\
\hline Mode & 3 \\
\hline Standard Deviation & 0.89 \\
\hline Sample Variance & 0.80 \\
\hline Kurtosis & -1.875 \\
\hline Skewness & 0.000 \\
\hline Range & 2 \\
\hline Minimum & 1 \\
\hline Maximum & 3 \\
\hline Sum & 12 \\
\hline Count (nets) & 6 \\
\hline Confidence Level (95.0\%) & 0.94 \\
\hline
\end{tabular}

\begin{tabular}{|l|r|}
\hline \multicolumn{2}{|c|}{ Yellow Perch 2004 } \\
\hline Mean (fish/net) & 0.5 \\
\hline Relative Standard Error (\%) & 68.31 \\
\hline Standard Error & 0.3 \\
\hline Median & 0 \\
\hline Mode & 0 \\
\hline Standard Deviation & 0.84 \\
\hline Sample Variance & 0.70 \\
\hline Kurtosis & 1.429 \\
\hline Skewness & 1.537 \\
\hline Range & 2 \\
\hline Minimum & 0 \\
\hline Maximum & 2 \\
\hline Sum & 3 \\
\hline Count (nets) & 6 \\
\hline Confidence Level (95.0\%) & 0.88 \\
\hline
\end{tabular}

\begin{tabular}{|l|r|}
\hline \multicolumn{2}{|c|}{ Lake Whitefish 2004 } \\
\hline Mean (fish/net) & 11.5 \\
\hline Relative Standard Error (\%) & 12.04 \\
\hline Standard Error & 1.4 \\
\hline Median & 12 \\
\hline Mode & \#N/A \\
\hline Standard Deviation & 3.39 \\
\hline Sample Variance & 11.50 \\
\hline Kurtosis & -1.442 \\
\hline Skewness & 0 \\
\hline Range & 9 \\
\hline Minimum & 7 \\
\hline Maximum & 16 \\
\hline Sum & 69 \\
\hline Count (nets) & 6 \\
\hline Confidence Level (95.0\%) & 3.56 \\
\hline
\end{tabular}

Appendix 6.4. Walleye condition factor and hooking injury, Pigeon Lake. 2004. 
Pigeon Lake Fall Walleye, Sander vitreus, Index Netting Survey, 2004; Data Report

\begin{tabular}{|c|c|c|c|c|c|c|}
\hline & CODE & $\begin{array}{l}\text { Mat. } \\
\text { Male }\end{array}$ & $\begin{array}{l}\text { Imm. } \\
\text { Male }\end{array}$ & $\begin{array}{c}\text { Mat. } \\
\text { Female }\end{array}$ & $\begin{array}{c}\text { Imm. } \\
\text { Female }\end{array}$ & Unknown \\
\hline Unusually Fat / No Injuries & 1.0 & 2 & & 5 & 1 & \\
\hline Unusually Fat / Mouth Mandible & 1.1 & & & & & \\
\hline Unusually Fat / Eye Injury & 1.2 & & & & & \\
\hline Unusually Fat / Internal Injury & 1.3 & & & & & \\
\hline Normal / No Injuries & 2.0 & 80 & 4 & 88 & 40 & 10 \\
\hline Normal / Mouth Mandible & 2.1 & 1 & & 2 & & \\
\hline Normal / Eye Injury & 2.2 & & & & & \\
\hline Normal / Internal Injury & 2.3 & & & & & \\
\hline Unusually Skinny / No Injuries & 3.0 & 2 & & & & \\
\hline Unusually Skinny / Mouth Mandible & 3.1 & & & & & \\
\hline Unusually Skinny / Eye Injury & 3.2 & & & & & \\
\hline Unusually Skinny / Internal Injury & 3.3 & & & 1 & & \\
\hline
\end{tabular}

Appendix 6.5. Walleye stocking shipments, Pigeon Lake, 1994-1999. 
Pigeon Lake Fall Walleye, Sander vitreus, Index Netting Survey, 2004; Data Report

\begin{tabular}{|c|c|c|c|c|c|c|c|}
\hline Year & $\begin{array}{c}\text { Stocking } \\
\text { Date }\end{array}$ & $\begin{array}{c}\text { Strain } \\
\text { Code }\end{array}$ & $\begin{array}{c}\text { Number } \\
\text { Stocked }\end{array}$ & $\begin{array}{c}\text { Ave. } \\
\text { Length } \\
(\mathrm{mm})\end{array}$ & Lot Usage & $\begin{array}{c}\text { Ave. } \\
\text { Weight } \\
(\mathrm{g})\end{array}$ & $\begin{array}{c}\text { Shipped } \\
(\mathrm{kg})\end{array}$ \\
\hline 1994 & 2-Jun-94 & BS & 5292269 & & Fry & & \\
\hline 1995 & 3-Jun-95 & DEF & 4876500 & & Fry & & \\
\hline 1996 & 9-Jun-96 & PR & 7355113 & & & & 21.3 \\
\hline 1997 & 2-Jul-97 & DEF & 95486 & 33.0 & Fingerling & 0.22 & 20.42 \\
\hline 1997 & 3-Jul-97 & DEF & 70558 & 33.0 & Fingerling & 0.29 & 24.9 \\
\hline 1997 & 4-Jul-97 & DEF & 90876 & 33.0 & Fingerling & 0.27 & 17.715 \\
\hline 1998 & 23-Jun-98 & DEF & 131746 & 40.0 & Fingerling & 0.38 & 56.3 \\
\hline 1998 & 25-Jun-98 & DEF & 40445 & 40.0 & Fingerling & 0.44 & 17.6 \\
\hline 1998 & 25-Jun-98 & DEF & 128539 & 40.0 & Fingerling & 0.44 & 23.3 \\
\hline 1999 & 29-Jun-99 & DEF & 77193 & 29.8 & Fingerling & 0.23 & 19.6 \\
\hline 1999 & 1-Jul-99 & DEF & 110427 & 29.8 & Fingerling & 0.21 & 251 \\
\hline 1999 & 2-Jul-99 & DEF & 125641 & 29.8 & Fingerling & 0.16 & \\
\hline
\end{tabular}

Appendix 6.6. Walleye catches by mesh size, Pigeon Lake 2003. 
Pigeon Lake Fall Walleye, Sander vitreus, Index Netting Survey, 2004; Data Report

\begin{tabular}{|c|c|c|c|c|c|c|c|c|c|c|c|c|}
\hline \multicolumn{13}{|l|}{ WALL } \\
\hline \multirow{2}{*}{ Set \# } & \multirow[b]{2}{*}{ Depth $(m)$} & \multirow{2}{*}{ Easting } & \multirow{2}{*}{ Northing } & \multicolumn{9}{|c|}{ Mesh Size $(\mathrm{mm})$} \\
\hline & & & & 25 & 38 & 51 & 64 & 76 & 102 & 127 & 152 & Total \\
\hline 1 & 8.5 & 698749 & 5876078 & 2 & 7 & 10 & 6 & 13 & 7 & 7 & 5 & 57 \\
\hline 2 & 2.5 & 689727 & 5881568 & 1 & 3 & 10 & 12 & 11 & 6 & 1 & 1 & 45 \\
\hline 3 & 8.5 & 697224 & 5878035 & 1 & 7 & 5 & 10 & 13 & 10 & 6 & 1 & 53 \\
\hline 4 & 2.5 & 691226 & 5884059 & 2 & 3 & 7 & 11 & 8 & 11 & 0 & 0 & 42 \\
\hline Total & & & & 6 & 20 & 32 & 39 & 45 & 34 & 14 & 7 & 197 \\
\hline CUE & & & & 1.50 & 5.00 & 8.00 & 9.75 & 11.25 & 8.50 & 3.50 & 1.75 & 49.25 \\
\hline
\end{tabular}





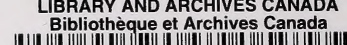

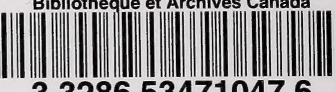

33286534710476 